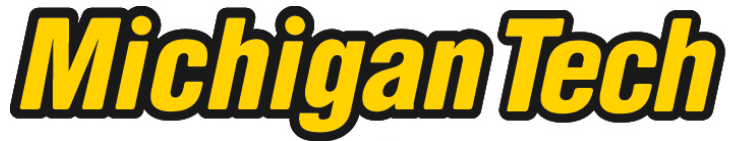 \\ Michigan Technological University Create the Future Digital Commons @ Michigan Tech
}

FOSSIL PLANTS AND PALYNOMORPHS FROM THE LATE PALEOZOIC CUTLER FORMATION, EASTERN PARADOX BASIN

Kendall R. Grazul

Michigan Technological University

Follow this and additional works at: https://digitalcommons.mtu.edu/etds

Part of the Earth Sciences Commons, and the Science and Mathematics Education Commons Copyright 2015 Kendall R. Grazul

\section{Recommended Citation}

Grazul, Kendall R., "FOSSIL PLANTS AND PALYNOMORPHS FROM THE LATE PALEOZOIC CUTLER FORMATION, EASTERN PARADOX BASIN", Master's report, Michigan Technological University, 2015.

https://doi.org/10.37099/mtu.dc.etds/910

Follow this and additional works at: https://digitalcommons.mtu.edu/etds

Part of the Earth Sciences Commons, and the Science and Mathematics Education Commons 


\title{
FOSSIL PLANTS AND PALYNOMORPHS FROM THE LATE PALEOZOIC CUTLER FORMATION, EASTERN PARADOX BASIN
}

By

Kendall R. Grazul

\begin{abstract}
A REPORT
Submitted in partial fulfillment of the requirements for the degree of MASTER OF SCIENCE

In Applied Science Education
\end{abstract}

MICHIGAN TECHNOLOGICAL UNIVERSITY

2015

(C) 2015 Kendall R. Grazul 
This report has been approved in partial fulfillment of the requirements for the Degree of MASTER OF SCIENCE in Applied Science Education.

Department of Cognitive and Learning Sciences

Report Advisor: $\quad$ Jacqueline E. Huntoon, Ph.D.

Committee Member: $\quad$ Bradley H. Baltensperger, Ph.D.

Committee Member: $\quad$ Jennifer M.K. O'Keefe, Ph.D.

Department Chair: $\quad$ Susan L. Amato-Henderson, Ph.D. 


\section{PREFACE}

This report is submitted in partial fulfillment of the requirements for the degree of Master of Science in Applied Science Education. This degree consists of a combination of science education core courses, applied science core courses, field courses, and a graduate research report. I chose the Earth Systems Science Track in order to enhance my understanding of processes that students can observe in everyday life. A firm understanding of the natural world and the nature of scientific inquiry can help to make teaching science more meaningful. My graduate report has focused on science content as opposed to a report solely focused on education in a classroom setting. I chose this path as an opportunity to achieve a hands-on and content-focused research experience. I wanted to do the work of a real scientist and bring that knowledge with me back to the classroom.

This report has impacted my views of science education and how I teach in the classroom. When students are provided with all of the procedures and answers, we deprive them of the chance for discovery. In reality, science is a dynamic and active discipline with many opportunities for young people. Using inquiry is just one of the ways to incorporate the true nature of science into a classroom. I want my students to think and behave like scientists, rather than just learn to replicate what others have done. My experience in doing this report has helped to solidify my understanding of science and my ability to incorporate scientific practices into my classroom instruction. As teachers work to follow the framework of the Next Generation Science Standards, there will be a shift from a broad array of content standards to a more integrated approach with practices and concepts working together. I believe I now have the expertise to bring science alive as a way of knowing and not just a collection of facts. Through this report, I feel that I have a clearer understanding of a more complete K-12 science education that reflects the interconnected nature of science as it is practiced and experienced in the real world. 


\begin{abstract}
The late Paleozoic Cutler Formation, where exposed near the modern-day town of Gateway, Colorado, has traditionally been interpreted as the product of alluvial fan deposition within the easternmost portion of the Paradox Basin. The Paradox Basin formed between the western margin of the Uncompahgre Uplift segment of the Ancestral Rocky Mountains and the western paleoshoreline of the North American portion of Pangea. The Paradox Basin region is commonly thought to have experienced semi-arid to arid conditions and warm temperatures during the Pennsylvanian and Permian. Evidence described in this paper support prior interpretations regarding paleoclimate conditions and the inferred depositional environment for the Cutler Formation near Gateway, Colorado.
\end{abstract}

Plant fossils collected from the late Paleozoic Cutler Formation in The Palisade Wilderness Study Area (managed by the U.S. Department of the Interior, Bureau of Land Management) of western Colorado include Calamites, Walchia, Pecopteris, and many calamitean fragments. The flora collected is interpreted to have lived in an arid or semi-arid environment that included wet areas of limited areal extent located near the apex of an alluvial fan system. Palynological analysis of samples collected revealed the presence of the common Pennsylvanian palynomorphs Thymospora pseudothiessenii and Lophotriletes microsaetosus. These fossils suggest that warm and at least seasonally and locally wet conditions existed in the area during the time that the plants were growing.

All evidence of late Paleozoic plant life collected during this study was found along the western margin of the Uncompahgre Uplift segment of the Ancestral Rocky Mountains. During the late Paleozoic, sediment was eroded from the Uncompahgre Uplift and deposited in the adjacent Paradox Basin. The preservation of plant fossils in the most proximal parts of the Paradox Basin is remarkable due to the fact that much of the proximal Cutler Formation consists of conglomerates and sandstones deposited as debris flow and by fluvial systems. The plants must have grown in a protected setting, possibly an abandoned channel on the alluvial fan, and been rapidly buried in the subsiding Paradox Basin. It is likely that there was abundant vegetation in and adjacent to low-lying wet areas at the time the Cutler Formation was deposited. 


\section{INTRODUCTION}

This study focuses on the paleobotany and palynology of the late Paleozoic Cutler Formation in the vicinity of Gateway, Colorado. For this study, samples were collected from sites located within The Palisade Wilderness Study Area (WSA) / Outstanding Natural Area (ONA) / Area of Critical Environmental Concern (ACEC), which is managed by the Grand Junction Field Office of the U.S. Department of Interior, Bureau of Land Management. The Palisade WSA is located in western Colorado, approximately 30 miles southwest of Grand Junction (figure 1). The Palisade WSA is named for the most prominent geographic feature in the area - The Palisade. The Palisade is a narrow ribbon-like mesa that rises abruptly from the surrounding area (figure 2A). A layer-cake succession of late Paleozoic to Jurassic aged strata is exposed in the cliff faces that comprise the margins of The Palisade.

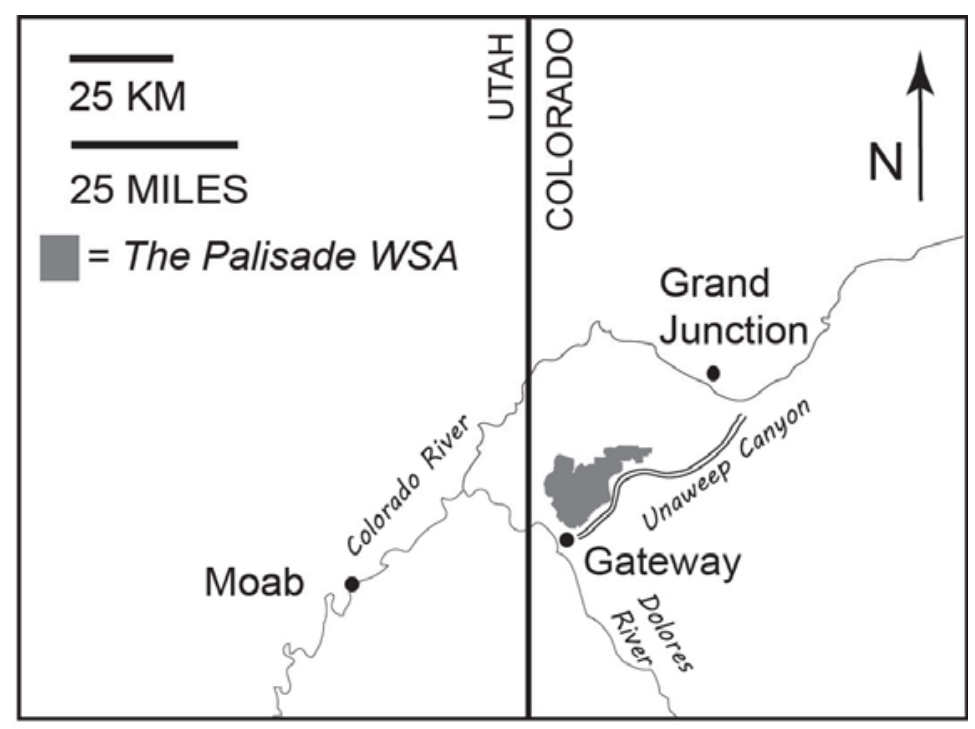

Figure 1. Location of The Palisade WSA in western Colorado. Colorado River, Dolores River and Unaweep Canyon shown on map.

In contrast to The Palisade itself, the majority of The Palisade WSA consists of relatively subdued topography formed on the late Paleozoic Cutler Formation. The Cutler Formation was deposited in the easternmost part of the Paradox Basin during the Pennsylvanian and Permian. Exposures of the Cutler Formation in The Palisade WSA include some of the most proximal deposits contained within the formation. In the study area, the Cutler Formation was deposited immediately adjacent to the western side of the Uncompahgre Uplift portion of the Ancestral Rocky Mountains. Today, canyons and gullies carved by ephemeral streams provide outstanding three-dimensional exposures of the Cutler Formation in The Palisade WSA, making the area an ideal location for study of the proximal Cutler Formation (figure 2). 


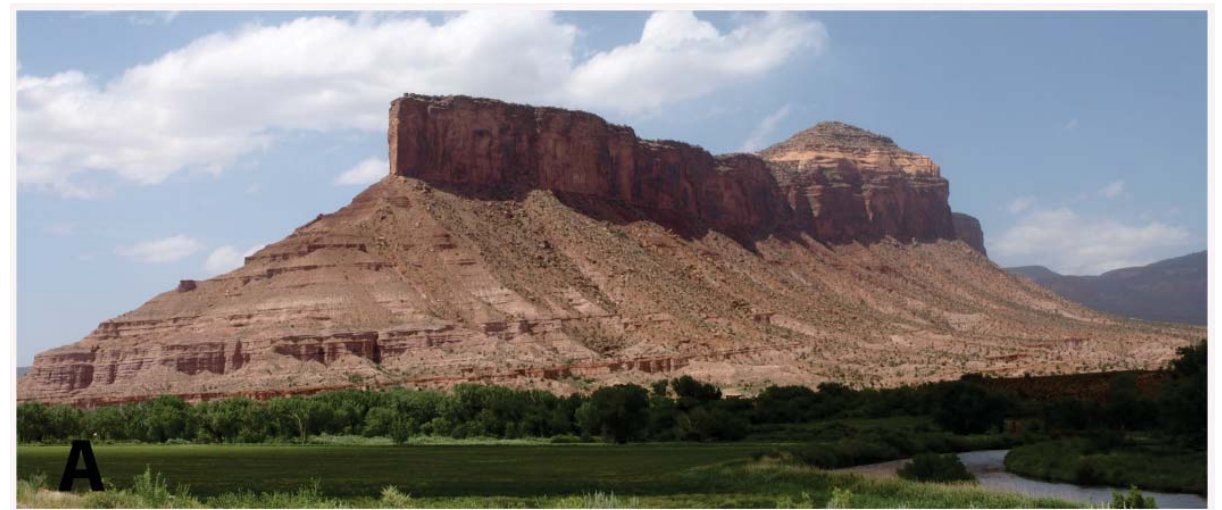

Figure 2. Field photographs of The Palisade WSA. A. The Palisade. B. Typical outcrop of Cutler Formation in The Palisade WSA including

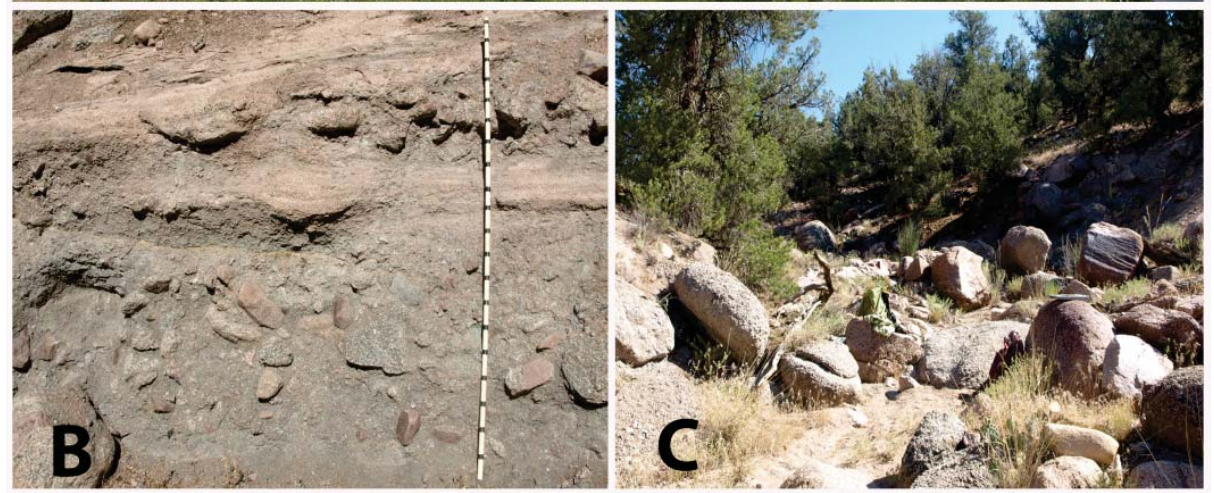
debris flow and sheetflood deposits (Jacob's staff $=$ 2 meters). C. View up one of the canyons within The Palisade WSA that was explored for

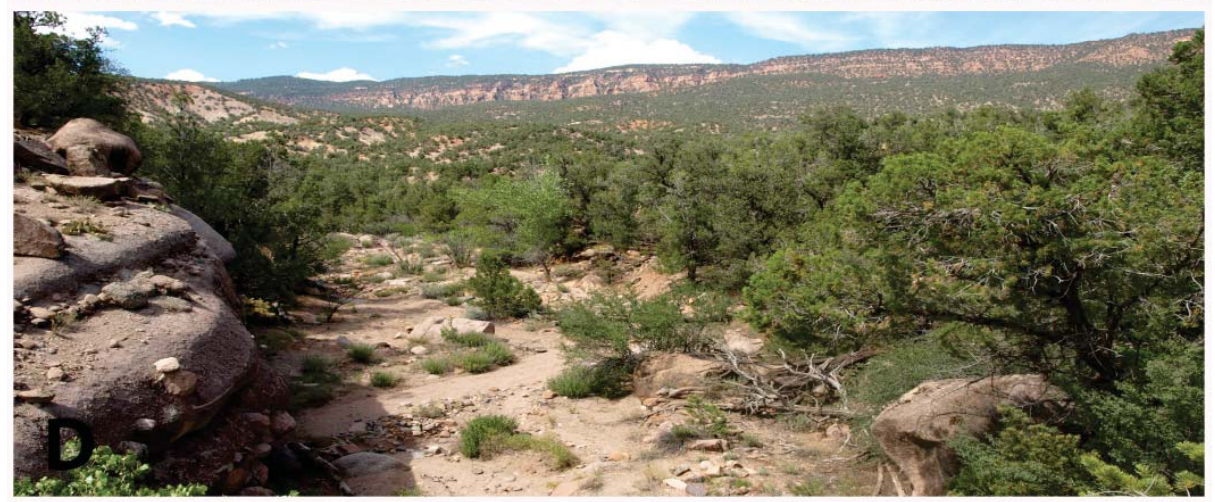
plant fossils. D. Cutler Formation outcrop on the far left with a view of the Unaweep Plateau in the background.

Exposures of the Cutler Formation near Gateway (Colorado) have traditionally been interpreted as the products of deposition by an alluvial fan (Walker, 1967; Werner, 1974; Campbell, 1979; Mack and Rasmussen, 1984; Campbell, 2003). The Cutler Formation near Gateway is commonly referred to as "the Gateway Fan." Despite the general agreement regarding the formation's depositional environment, attempts to characterize the climate at the time of deposition have resulted in considerable debate. Evidence has been presented to support interpretations ranging from ever-wet (Campbell, 1979), through seasonally wet 
and semi-arid to sub-humid (Mack and Rasmussen, 1984; Campbell, 2003), to semi-arid to arid (Walker, 1967; Werner, 1974) climate conditions at the time of deposition.

Interpretations of semi-arid to arid conditions are supported by the presence of halite, anhydrite, and gypsum in the Pennsylvanian Paradox Formation which was deposited in the central portion of the Paradox Basin during the Pennsylvanian (Hite and Buckner, 1981). The Paradox Formation may be, in part, a lateral equivalent to the oldest portions of the Cutler Formation (Condon, 1997). Younger lateral equivalents in the central and western Paradox Basin region include Permian sandstones deposited in eolian environments (e.g., Cedar Mesa Sandstone and White Rim Sandstone). These eolian sandstones, like the Paradox Formation, indicate arid conditions were dominant in the central Paradox Basin for extended periods during the time of deposition of the Cutler Formation (Nuccio and Condon, 1996).

In contrast to the traditional understanding of the Cutler Formation as the product of alluvial fan deposition, Soreghan and others (2009) interpreted the Cutler Formation in The Palisade WSA as a low-latitude glacio-lacustrine deposit. This hypothesis suggested that glaciers existed at low elevations and low latitudes in western Pangea during the late Paleozoic. More recently however, an analysis of plant fossils extracted from the proximal Cutler Formation led Huntoon and others (2014) to conclude that interpretations of an alluvial fan origin for the Cutler Formation near Gateway are justified.

In addition to Huntoon and others (2014), other studies have investigated plant fossils and pollen obtained from the proximal Cutler Formation (e.g., Werner, 1974; Mack and Rasmussen, 1984; Soreghan and others, 2007). The results of previous analyses provide a rich source of data that can be used to constrain interpretations regarding environmental conditions in the local area at the time of deposition of the Cutler Formation. The additional plant fossils and pollen evidence described in this paper support the interpretation of the Cutler Formation as an alluvial fan deposit. They also suggest that the climate in The Palisade WSA during the late Paleozoic was warm and that water was locally present on the upper reaches of the alluvial fan at the time of deposition. It appears that there was abundant vegetation in and adjacent to low-lying wet areas at the time the Cutler Formation was deposited. 


\section{GEOLOGIC SETTING}

During the late Paleozoic, the area that now makes up The Palisade WSA was located near the western margin of proto-North America at near-equatorial paleolatitudes (figure 3). The Palisade WSA was at that time bounded on the east by the southwestern faulted margin of the Uncompahgre Uplift. This uplift was the westernmost outlier of the Ancestral Rocky Mountains. Segments of the Ancestral Rocky Mountains extended across late Paleozoic North America (Ye and others, 1996).

The Uncompahgre Uplift was continuously eroded during the late Paleozoic and it contributed sediments that were deposited in the Paradox Basin, which was located to the west. The Cutler Formation in The Palisade WSA consists of sediment derived from the Uncompahgre Uplift (Werner, 1974) and deposited directly adjacent to its western margin in the easternmost part of the Paradox Basin. The Cutler Formation reaches its maximum thickness in proximal locations in the Paradox Basin, such as The Palisade WSA. The formation thins to the west and southwest across the Paradox Basin where it undergoes facies changes and is known as the Cutler Group (Condon, 1997). The lowermost part of the Cutler Formation and Group in areas more distal to the Uncompahgre Uplift than The Palisade WSA record cycles of marine flooding and evaporation in the Paradox Bain that resulted from long-term cycles of sea-level change during the late Paleozoic (Rankey, 1997).

In The Palisade WSA, the Cutler Formation typically consists of pastel-colored clastic rocks. Red, pink, maroon, lavender, and white conglomerates and sandstones predominate (Huntoon and others, 2014). Quartz and feldspar are the most abundant minerals, although biotite, hematite, epidote, muscovite, and opaque minerals are also common (Campbell, 2003). Although coarse sandstones and conglomerates are common in the Cutler Formation in The Palisade WSA, the fossils and palynomorphs described in this paper were extracted from relatively fine-grained facies.

Evidence exists that the proximal Cutler Formation was vegetated during the late Paleozoic. Recently, Huntoon and others (2014) described plants fossils from the Cutler Formation, including Pecopteris, Calamites, Archaeocalamites, and Neuropteris. All of these plants are thought to have lived in environments with a high water table for a large portion of the year (Tidwell, 1998). Additionally, Mack and Rasmussen (1984) documented the presence of rhizocretions in the proximal Cutler Formation and Soreghan and others (2007) identified late Paleozoic palynomorphs (Densosporites, Lycospora, Vesicaspora, and Florinites) in samples collected in and near The Palisade WSA. 


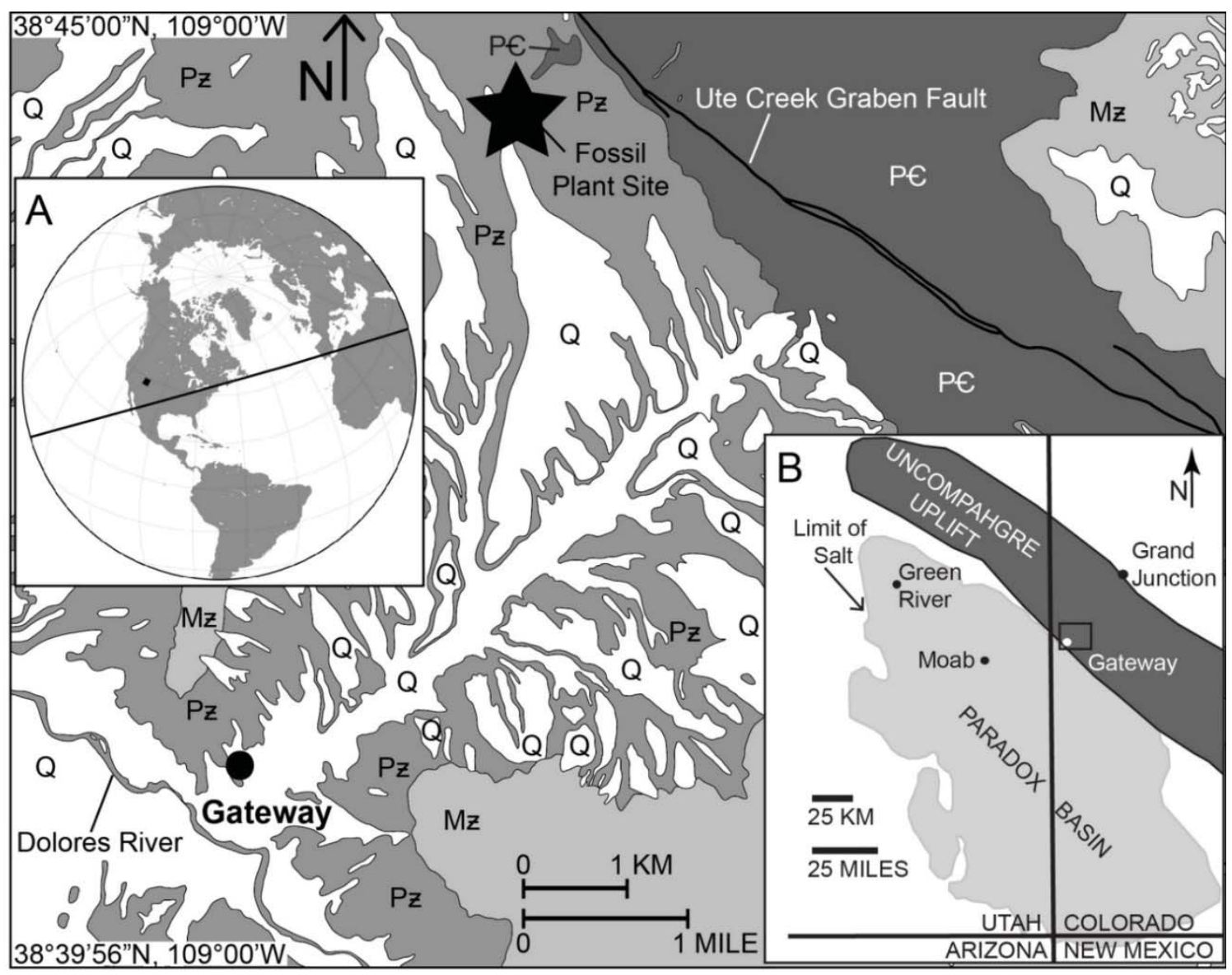

Figure 3. Study area (modified from Huntoon and others, 2014). Surface geology modified from Cater (1955): $\mathrm{PC}=$ Precambrian rocks (dark gray); $\mathrm{PZ}=$ Paleozoic Cutler Formation (medium gray); $\mathrm{MZ}=$ Mesozoic strata (light gray); $\mathrm{Q}=$ Quaternary alluvium (white). Latitude and longitude shown for the northwest and southwest corners of the map. Inset A. Location of study area and late Paleozoic paleoequator (calculated by Smirnov, personal communication, 2011). Inset B. Location of study area; small rectangle enclosing Gateway is shown expanded as the main map in this figure.

\section{METHODS}

The goals of this study are to document the locations of fossil-bearing strata in the Cutler Formation in The Palisade WSA, map the occurrence of strata that are similar in lithology to the fossil-bearing strata, and determine whether or not fossil palynomorphs are present in the formation. In order to achieve these goals, fieldwork was conducted in the summer 
of 2014. Field investigations focused on the area located to the west of the mouth of Unaweep Canyon, to the north of West Creek and to the south and east of the topographic promontory known as The Palisade (figures 1 and 3). The area was mapped and samples were collected and transported to Michigan Technological University for further analysis.

\section{Field Mapping}

The field study covered areas located on the Gateway and Two V Basin 7.5 minute topographic quadrangle maps. Locations were determined using hand-held Garmin GPS units and the 1:24,000 scale topographic maps (Gateway \& Two V Basin). Draws, side canyons, and ridges were explored in search of plant fossils. At the same time, the contact between the Cutler Formation and the Precambrian rocks that formed the core of the Uncompahgre Uplift was traced and mapped. When fossil-bearing rocks were encountered, their locations were indicated on the field map. The occurrences of rocks with a lithology similar to the fossil-bearing strata were also mapped.

Fossil plants and plant fragments were collected from two sites (USNM 43857 and USNM 43856). It is important to note that these sites are subdivisions of a prior collection site (USNM 43705) described in Huntoon and others (2014). The fossils were photographed, and transported from the field for description and identification in the laboratory. Hand samples were collected from the two fossil-bearing sites and from one non-productive layer (USNM 43858) that was similar in lithology to the fossil-bearing rock. These hand samples were later processed in the laboratory as part of the palynological analysis. Although fossil plants were only found at two sites, the non-productive sites with similar lithologies could potentially contain fossils or palynomorphs, even though none were found during this study.

\section{Sample Processing}

\section{Plant Fossils}

Plant fossils were collected from two sites. The samples were photographed and numbered in the field, carefully packed, and then transported to Michigan Technological University. Upon completion of the fieldwork, the samples were organized by type, renumbered, and re-photographed. Each fossil was described, and fine details were examined and sketched. Photographs and sketches were used to compare to plant fossils described in the literature in order to identify each specimen. All of the fossils are now housed in the type/illustrated 
collections of the National Museum of Natural History, Smithsonian Institution, Washington, D.C.

\section{Palynological Analysis}

Hand samples were taken to Morehead State University for palynological processing and analyses. The hand samples were crushed to pass through a 1-millimeter mesh sieve and 2-gram sub-samples were split from each crushed hand sample using a microriffler. The material was demineralized and deflocculated in preparation for the extraction of the organic material. The O'Keefe Method was used to process the samples (O'Keefe and others, 2011; O'Keefe and Eble, 2012). Permanent slides were prepared and inventoried for palynomorphs.

\section{RESULTS}

Plant fossils were only observed at and collected from two sites (figure 4). Despite careful searching, no other plant fossil localities were identified. Although lithofacies similar in color and grain size to the fossil-bearing units were encountered at several other sites, material exposed at the surface at the majority of those other sites was too unconsolidated to allow for successful collection of plant material, even if it was present. Extensive excavations were not undertaken however, so it is possible that better lithified material is present below the surface at some of those sites. It should be noted that fossils and relatively well-preserved palynomorphs were only collected from sites located close to the contact between the late Paleozoic Cutler Formation and the Precambrian granite and gneiss that once formed the core of the Uncompahgre Uplift (figure 5).। 


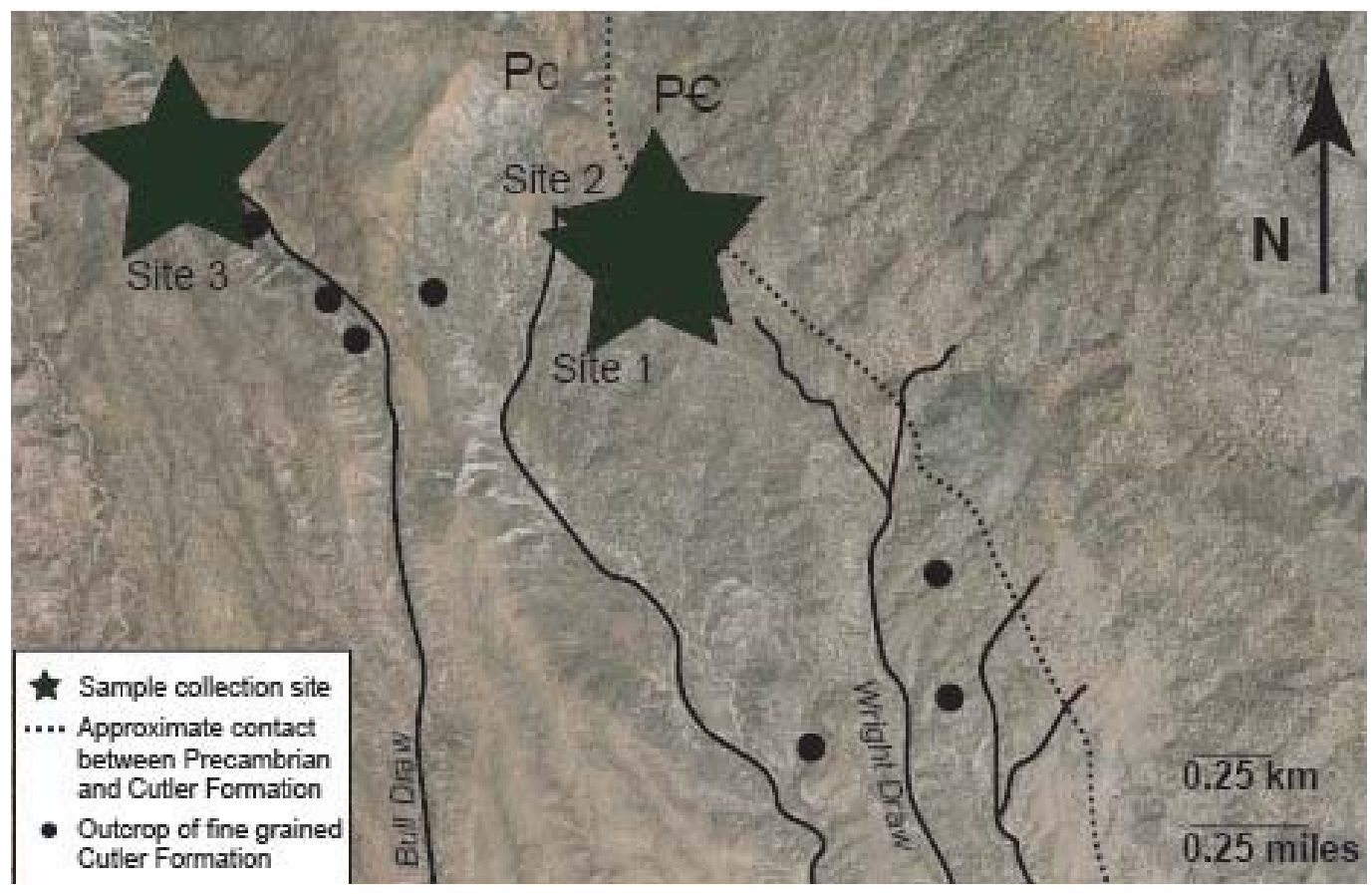

Figure 4. Field map of study area. Approximate location of sample collection sites labeled. Locality information available upon request to qualified researchers. Contact between Precambrian granite and gneiss (labeled PE) and late Paleozoic sedimentary Cutler Formation (labeled PC) shown. Plant fossil-bearing localities are located adjacent to the contact.

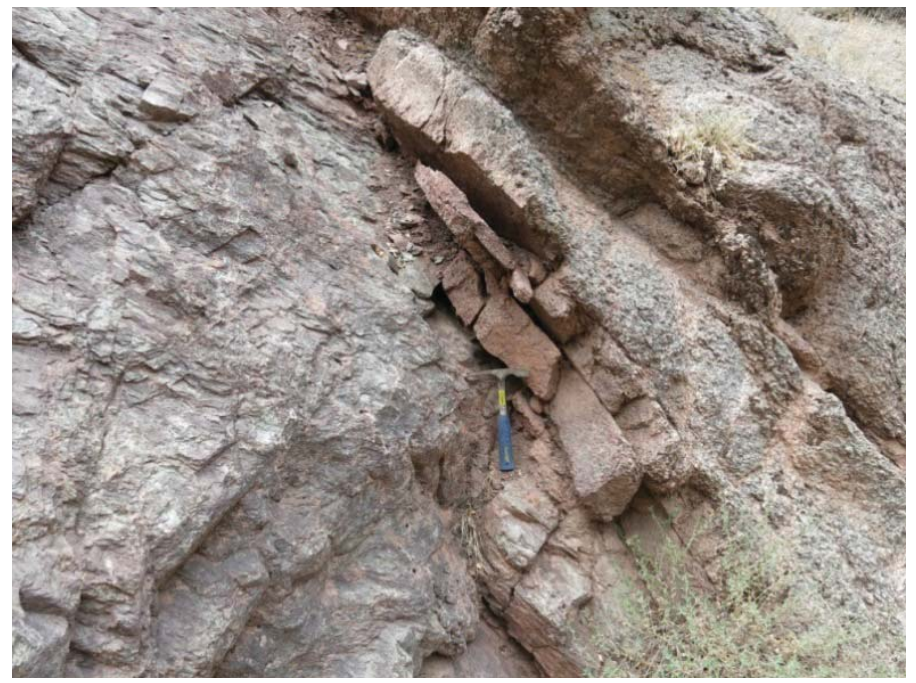

Figure 5. Example of faulted contact between late Paleozoic Cutler Formation and Precambrian rocks. Cutler Formation is exposed on the left side of the photo. Fault places Precambrian granite over Cutler Formation. Rock hammer lies along the trace of the faulted contact. 


\section{Site One}

The outcrop at Site 1 (USNM 43857) is approximately 3 meters thick and consists of three units, with the fossil bearing unit at the top (figures 6 and 7). The lowest layer included in the measured section (figure 6) is a dark gray, poorly sorted, matrix-supported boulder conglomerate. The base is not exposed. The lower unit contains sub-angular to sub-rounded randomly oriented clasts composed of granite and gneiss. The lower unit contains approximately $50 \%$ clasts with a maximum size of 35 centimeters and an average size of 5 centimeters. The matrix is very coarse to fine sandstone consisting of angular to subangular grains of quartz and feldspar. This unit is interpreted as a debris-flow deposit.

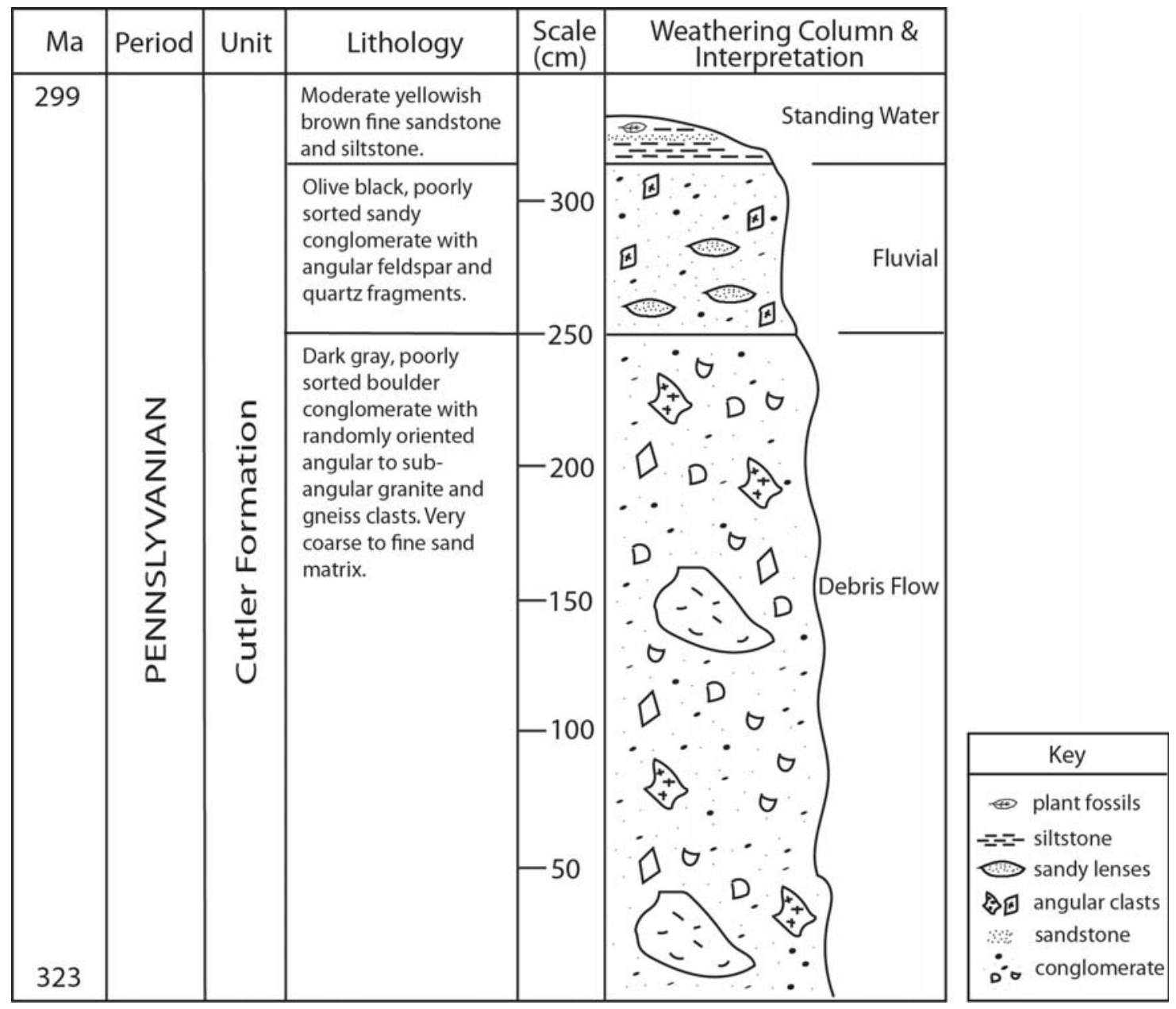

Figure 6. Measured section of Site 1. See main text for description. 

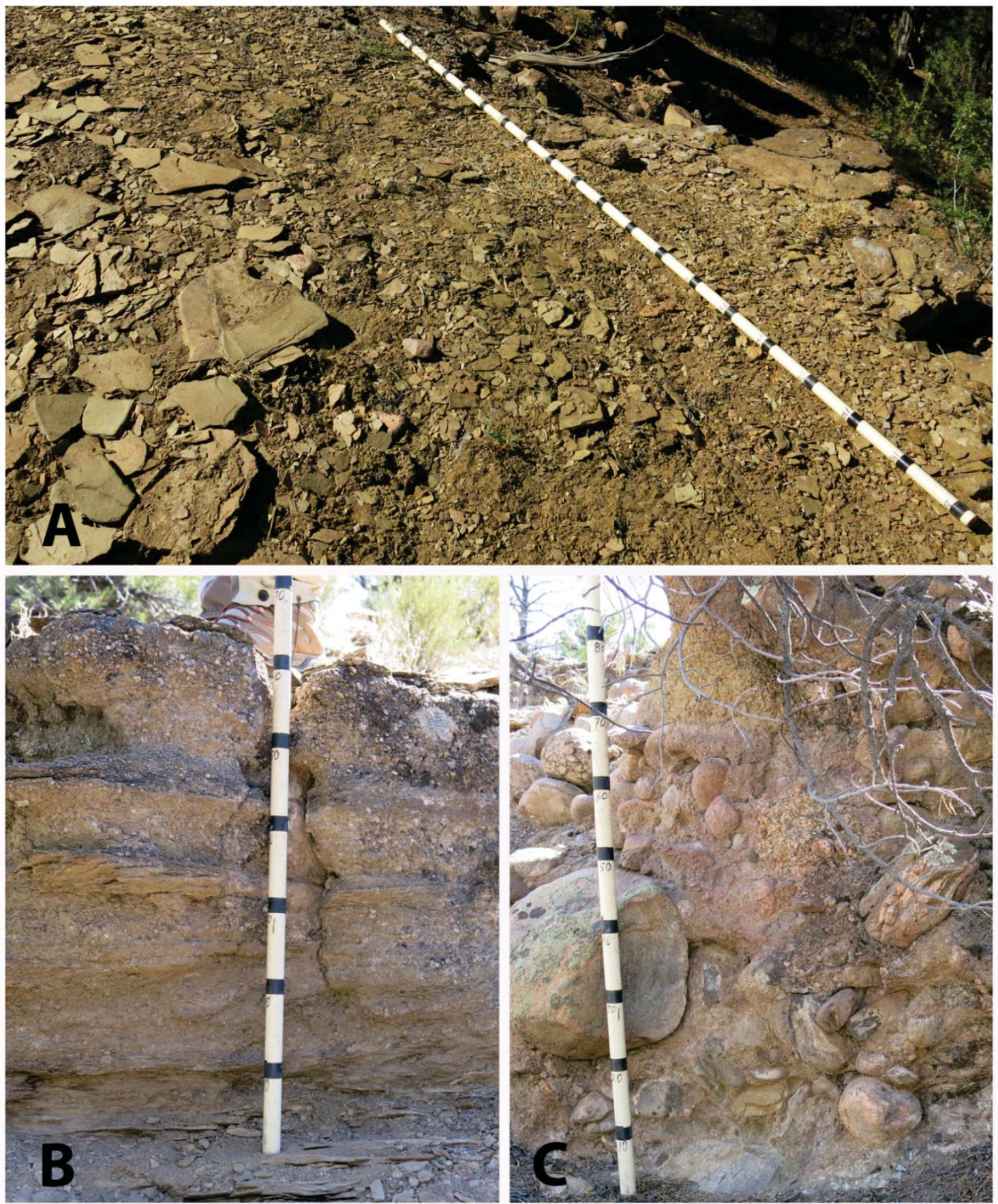

Figure 7. Field photographs of Site 1 (Jacob's staff marked in 10 centimeter increments). A. Surface view of top of fossil-bearing unit as it is exposed along the crest of a ridge. $\mathbf{B}$. Conglomerate and sandstone of the middle unit. C. Conglomeratic lower unit near base of exposure. 
The lowermost unit is overlain by an olive black, poorly sorted sandy conglomerate with angular clasts of feldspar and quartz. This middle unit contains approximately $40 \%$ clasts with a maximum size of 4 centimeters and an average size of 0.5 centimeters. The matrix consists of mudstone to very coarse sandstone. The middle unit contains alternating layers of relatively coarser and relatively finer layers with scattered lenses of sandstone and sandy siltstone on the order of 1-5 centimeters thick. The middle unit is interpreted as the product of fluvial deposition.

The uppermost unit at the site is the fossil-bearing layer. It has a maximum thickness of 10 centimeters and consists of moderate yellowish brown, thinly laminated, micaceous siltstone to fine sandstone. This unit is interpreted as the product of deposition under slackwater conditions due to the abundance of fine-grained material, including flakes of mica.

\section{Fossil Content}

Four distinct specimens of potentially identifiable plant fossils were collected from Site 1. Many small and incomplete calamitean fragments were also found at this location. The first group of identifiable specimens are all members of the genus Calamites. The best preserved specimen (figure 8) is 13.5 centimeters long and 3 centimeters wide. This sample appears to be an incomplete external stem cast (DiMichele and Falcon-Lang, 2012). The external surface of the cast is longitudinally ribbed with grooved indentations. The ribs are 0.1 centimeters wide. There are 3 nodes visible on the specimen and the ribs alternate at the nodes, as is typical of Calamites (Tidwell, 1998). The fossil is light brown in color and is present in a moderate yellowish brown siltstone.

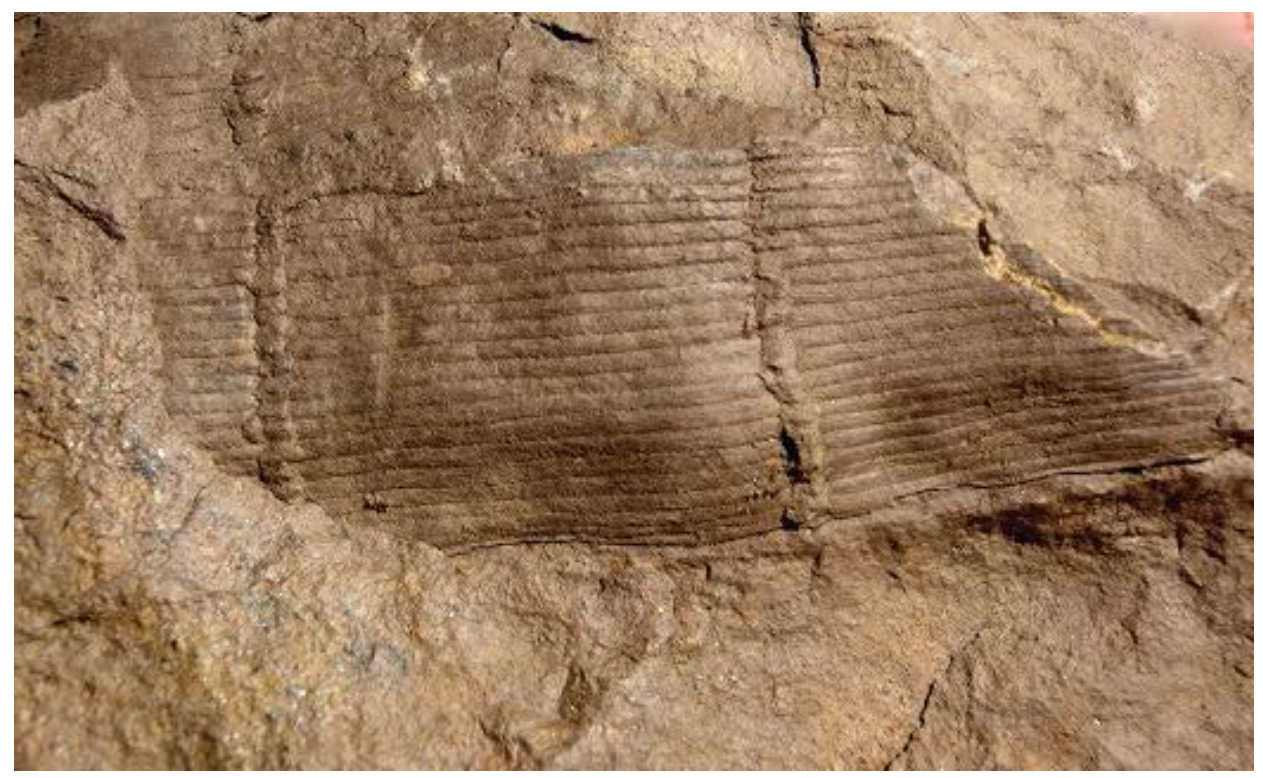

Figure 8.

Calamites

(specimen dimensions $=$ $13.5 \mathrm{~cm} \mathrm{x} 3$ cm). USNM Specimen 611005. USNM Site 43857. 
The Walchia specimen (figure 9) is 2.6 centimeters long. The width of the specimen varies between 0.3 and 0.5 centimeters. The scale-like leaves are oval and come to a point where they join the stem. Each leaf is approximately 0.2 centimeters long and 0.1 centimeters wide and is oriented at an acute angle to the center stem. Walchia is characterized by narrow branches with small, upright leaves that taper to a point (Arnold, 1941), as is apparent in this specimen. No veins are apparent on the impressions of individual leaves. The specimen is moderate yellowish brown and is present in a pale yellowish brown siltstone.

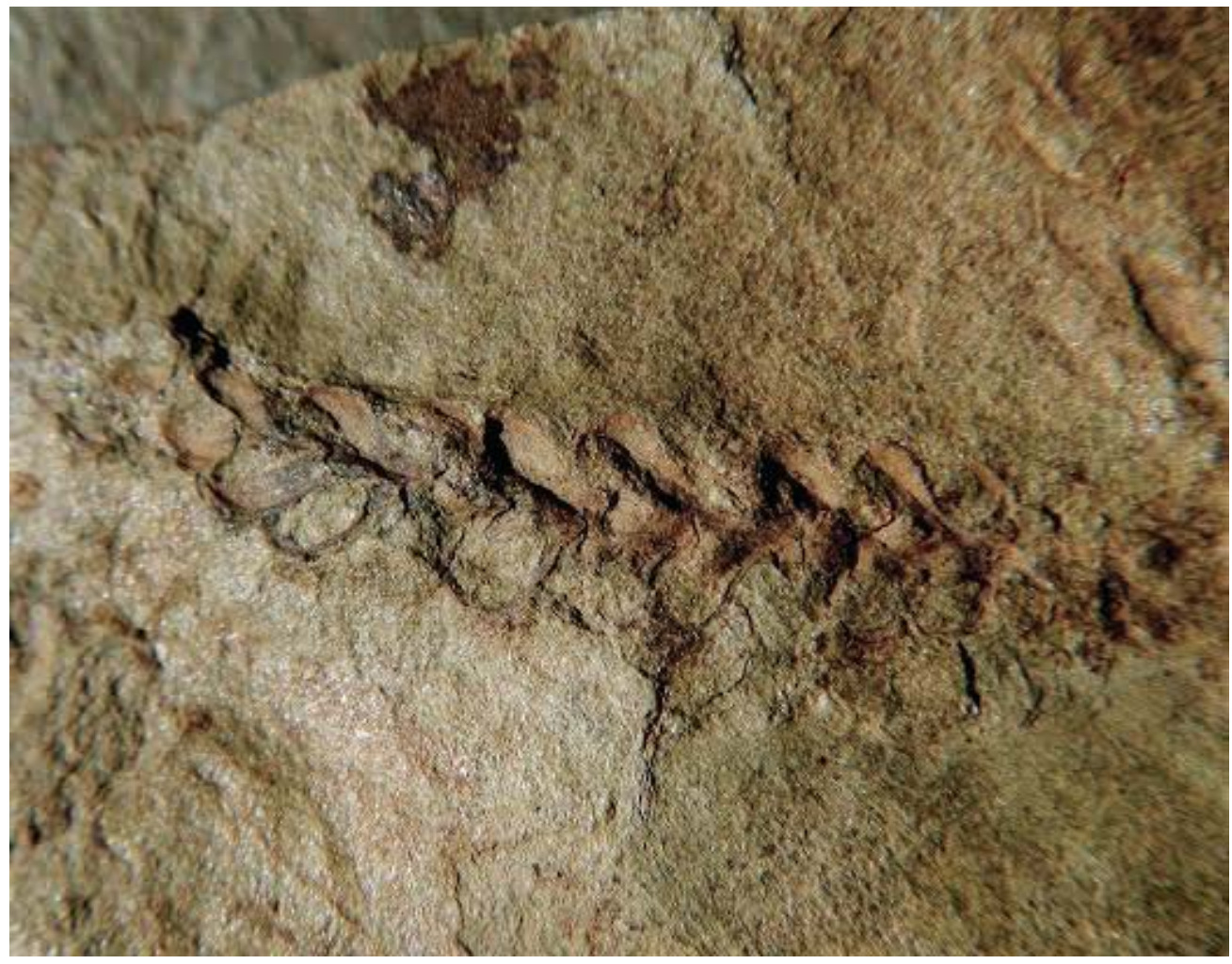

Figure 9.

Walchia (specimen dimensions $=2.6 \mathrm{~cm} \mathrm{x}$ $0.4 \mathrm{~cm})$. USNM Specimen 611006. USNM Site 43857.

The Pecopteris fossil (figure 10) has a rachis that is 15 centimeters long and 0.3 centimeters wide. The rachis is straight and heavy as is common for Pecopteris (Wittry, 2006). Pinnae are alternate along the stem. Some impressions of the pinnae are very faint, but those that are recognizable measure between 5 and 6 centimeters long and 0.5 to 1 centimeter wide. The pinnae come to a point at their distal ends. As is typical of Pecopteris, the pinnae consist of small pinnules with a broad basal attachment to the costa and slight confluence between adjacent pinnules (DiMichele and others, 2010). The stem is moderate brown, with both the fronds and surrounding siltstone moderate yellowish brown in color. 


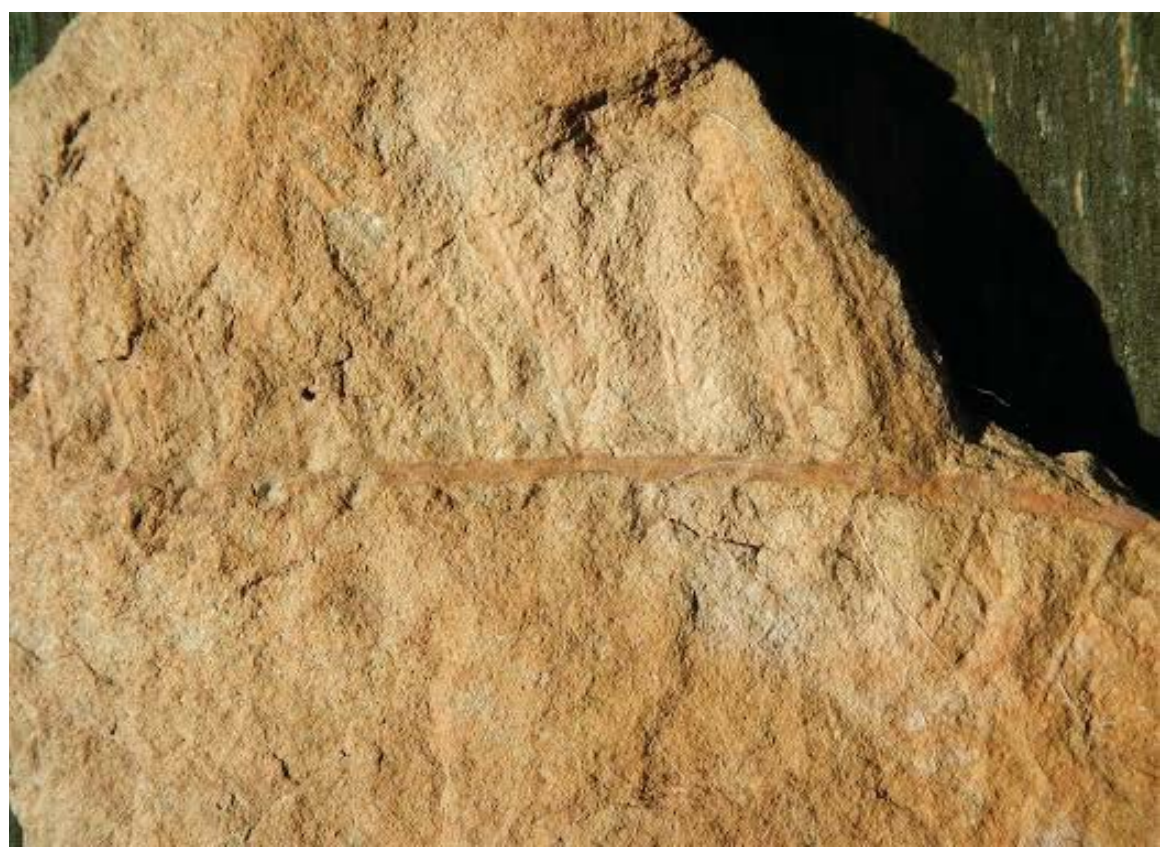

Figure 10.

Pecopteris

(specimen

dimensions $=15$

$\mathrm{cm} \times 8 \mathrm{~cm}$ ).

USNM Specimen

611007. USNM

Site 43857.

The last identifiable specimen found at Site 1 is another Pecopteris specimen (figure 11). The specimen is 5 centimeters long and 3 centimeters wide at the base. The pinnules, which are about 0.4 centimeters wide, get progressively smaller away from the base of the pinna. Pecopteris tends to have alternate, closely spaced, and straight-sided pinnules (Wittry, 2006). Each pinnule is rounded and has a well-defined rib in the center. The pinnules have flat bases where attached to the stem. The pecopterid is moderate yellowish brown in a pale yellowish brown siltstone.

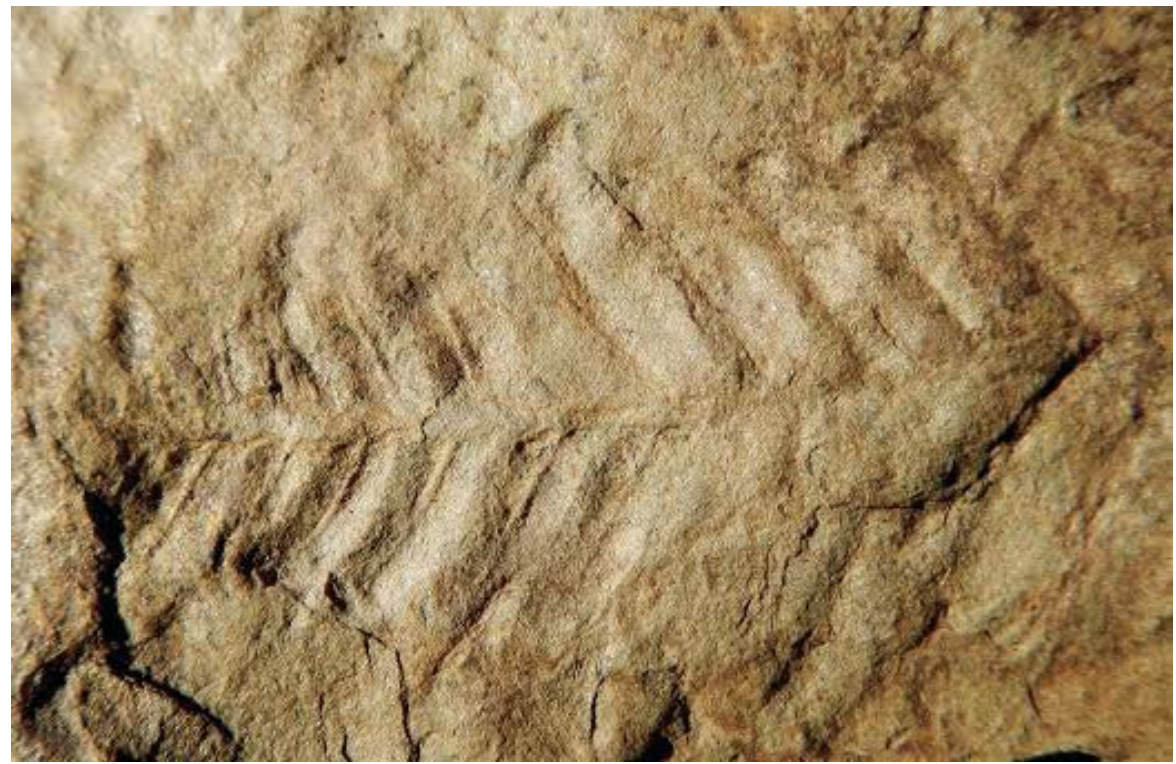

17
Figure 11.

Pecopteris (specimen dimensions $=5$ $\mathrm{cm} \times 3 \mathrm{~cm})$. USNM Specimen 611008. USNM Site 43857. 
Slides containing organic material extracted from the sample collected at Site 1 contained cellulosic tissue and degraded fern and fungal spores. A common Pennsylvanian fern spore, Lophotriletes microsaetosus, was most abundant (figure 12). Some cellulosic plant material contained ovoid fungal spores belonging to the Basidiosporites complex and displayed attached fungal hyphae, which indicate that the plant matter had been attacked by saprophytic fungi prior to preservation (figure 13). The sample shown in figure 13 clearly experienced fungal decay. The presence of soil-forming fungal spores indicates that highly oxygenated conditions were present in the near-surface.

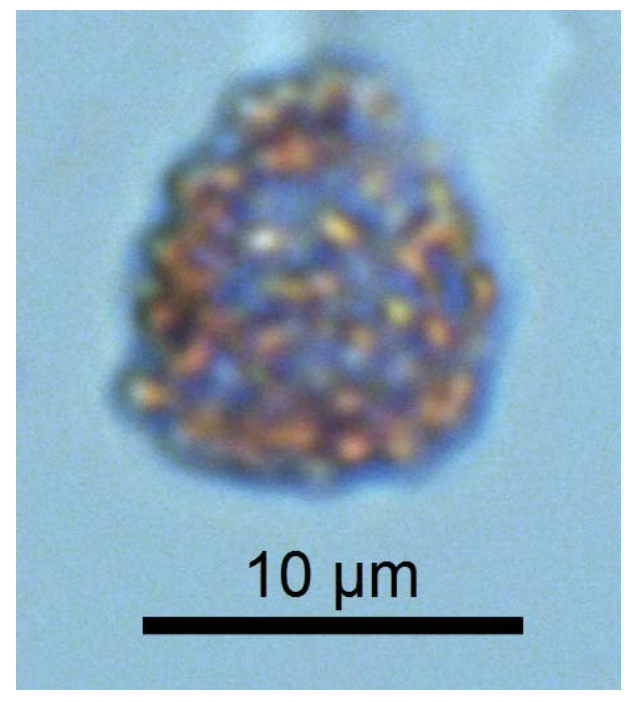

Figure 12. Degraded spore of Lophotriletes microsaetosus $($ scale bar $=10 \mu \mathrm{m})$. USNM Site 43857.

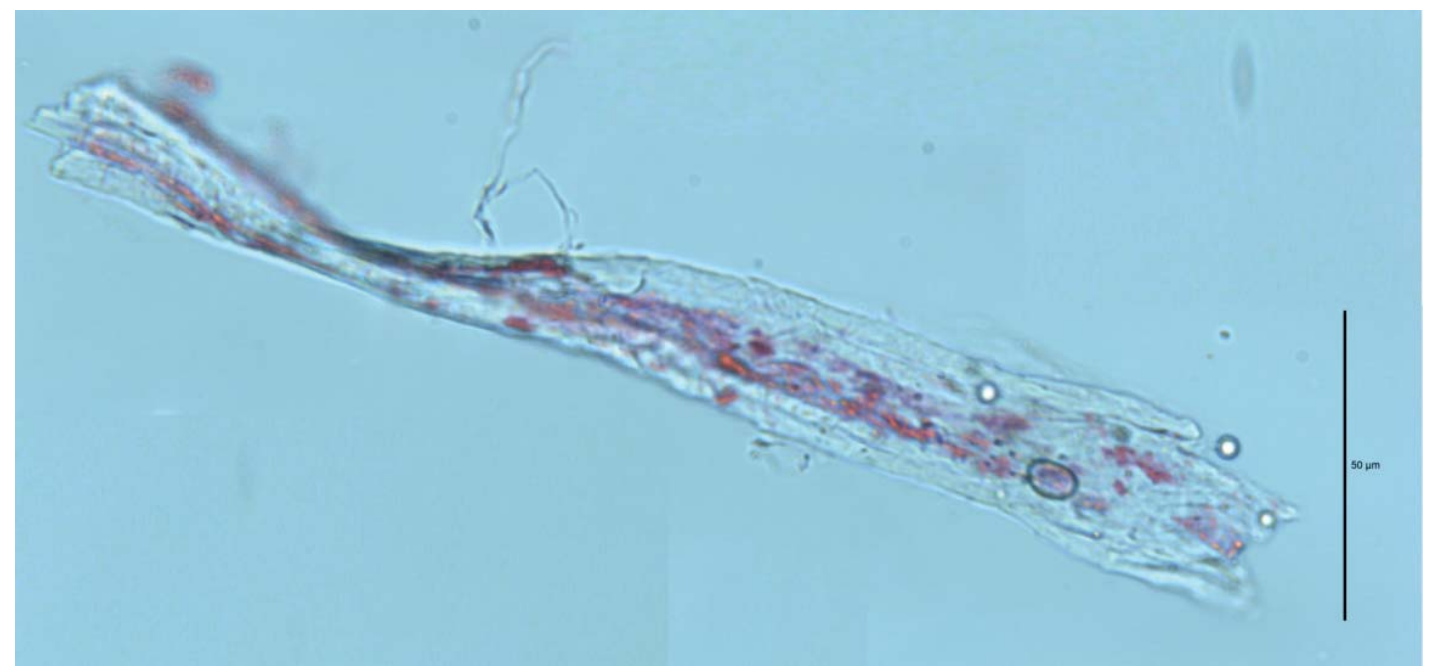

Figure 13. A cellulosic fragment with ovoid fungal spore and attached hyphae (vertical scale bar $=50 \mu \mathrm{m}$ ). USNM Site 43857 . 
The presence of modern hickory pollen (Carya texana; figure 14) and pine pollen (Pinus $s p$.; figure 15) indicate contamination of the sample by modern pollen. Neither existed in the late Paleozoic, therefore, a more recent wash-down event, possibly from as early as the Paleogene, may have carried these pollen into the late Paleozoic rocks.

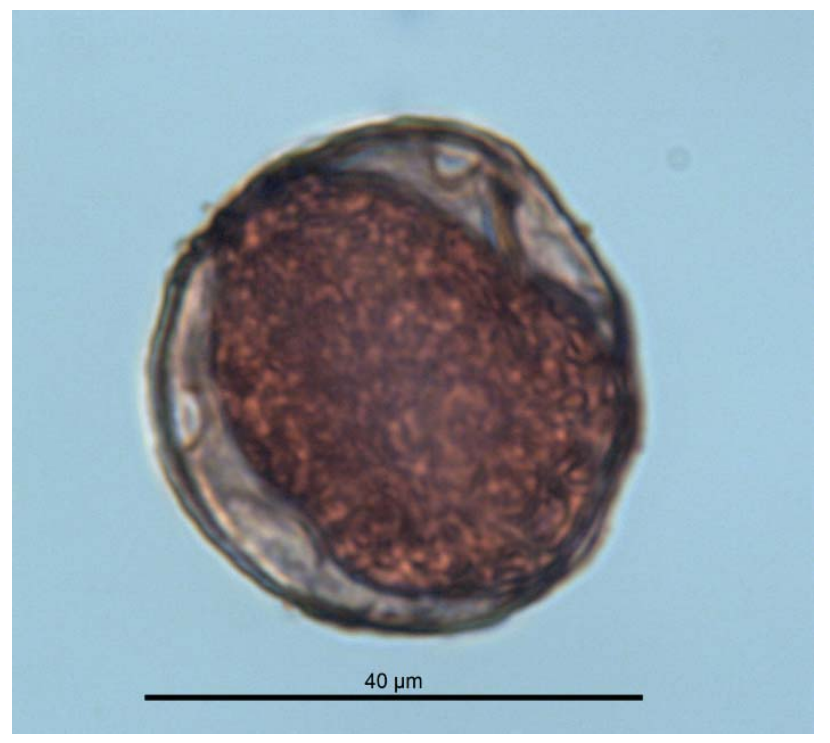

Figure 14. Carya texana $($ scale bar $=$ $40 \mu \mathrm{m})$. This specimen indicates contamination of the sample by material younger than late Paleozoic. USNM Site 43857.

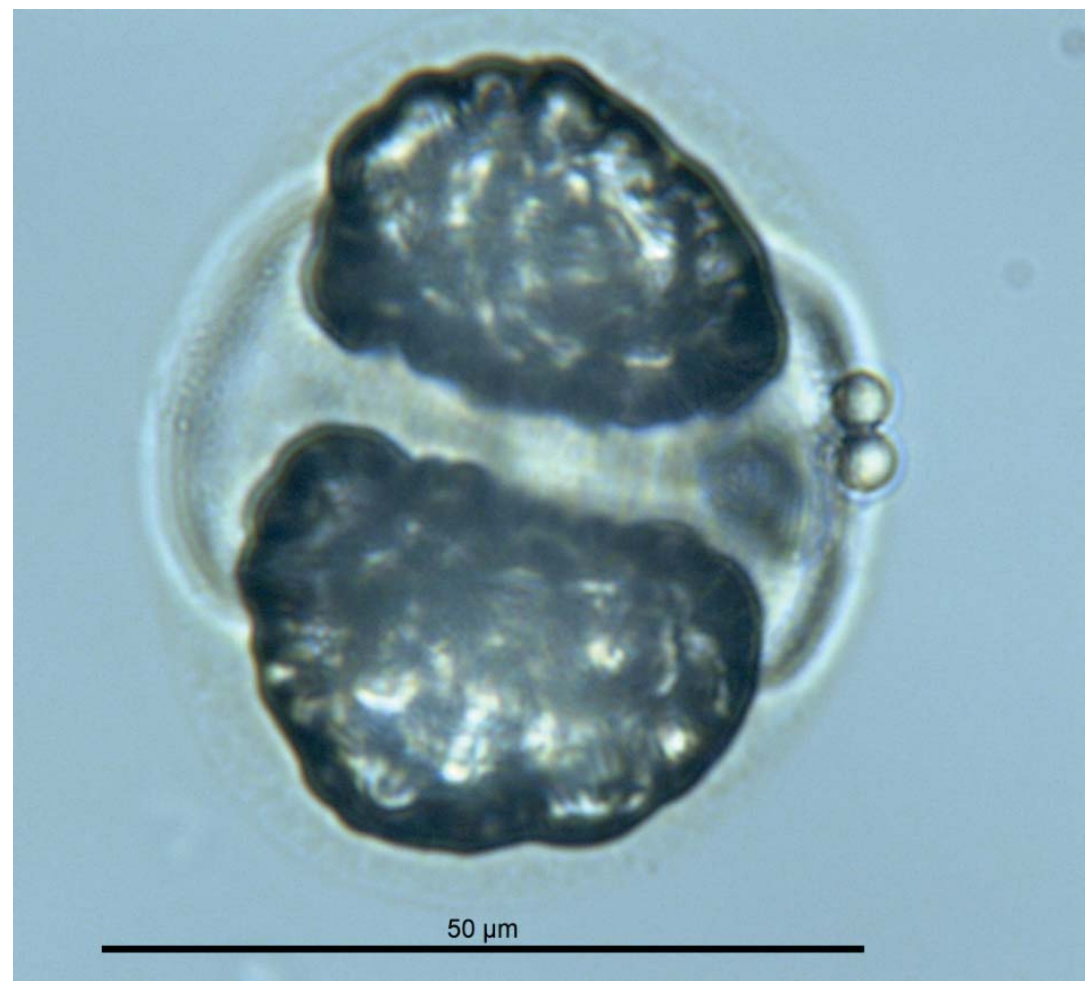

Figure 15. Pinus sp., in a bladders-up view (scale bar $=50 \mu \mathrm{m})$. This specimen indicates contamination of the sample by material younger than late Paleozoic. USNM Site 43857. 


\section{Site Two}

Site 2 (USNM 43856) is located very close to but stratigraphically below Site 1 . Site 2 is situated directly adjacent to the contact between the Cutler Formation and the Precambrian rocks of the Uncompahgre Uplift (figure 4). The outcrop at Site 2 is approximately 2 meters thick and consists of three units (figures 16-18). The upper and lower units are very similar to the weathered granite wash (middle unit) observed at Site 1 and described previously. The middle unit at Site 2, which contains plant fossils, is approximately 70 centimeters thick and consists of interlayered relatively coarse and relatively fine strata. The relatively coarse components of the unit are layers of medium to very coarse reddish orange sandstone less than 5 centimeters in thickness. The relatively fine layers consist of thinly laminated light olive gray very fine sandstone to micaceous sandy siltstone. The middle

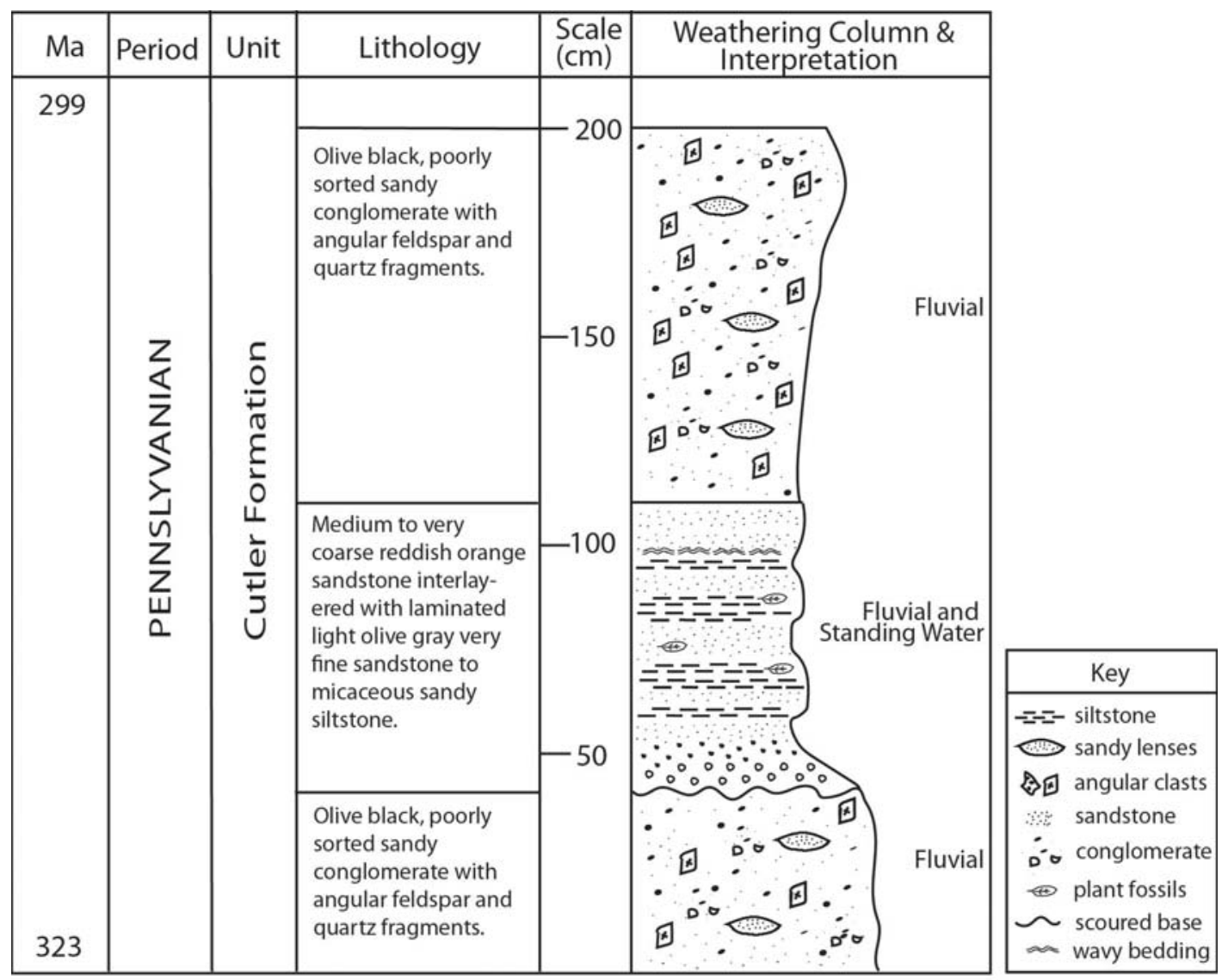

Figure 16. Measured section of Site 2. See main text for description. 
unit at Site 2 has a scoured basal boundary and fines upward overall. Most of the fossils at Site 2 were found within the relatively finer layers of the middle unit. Some of the thinly laminated micaceous layers show small-scale wavy deformation that is possibly due to compression.
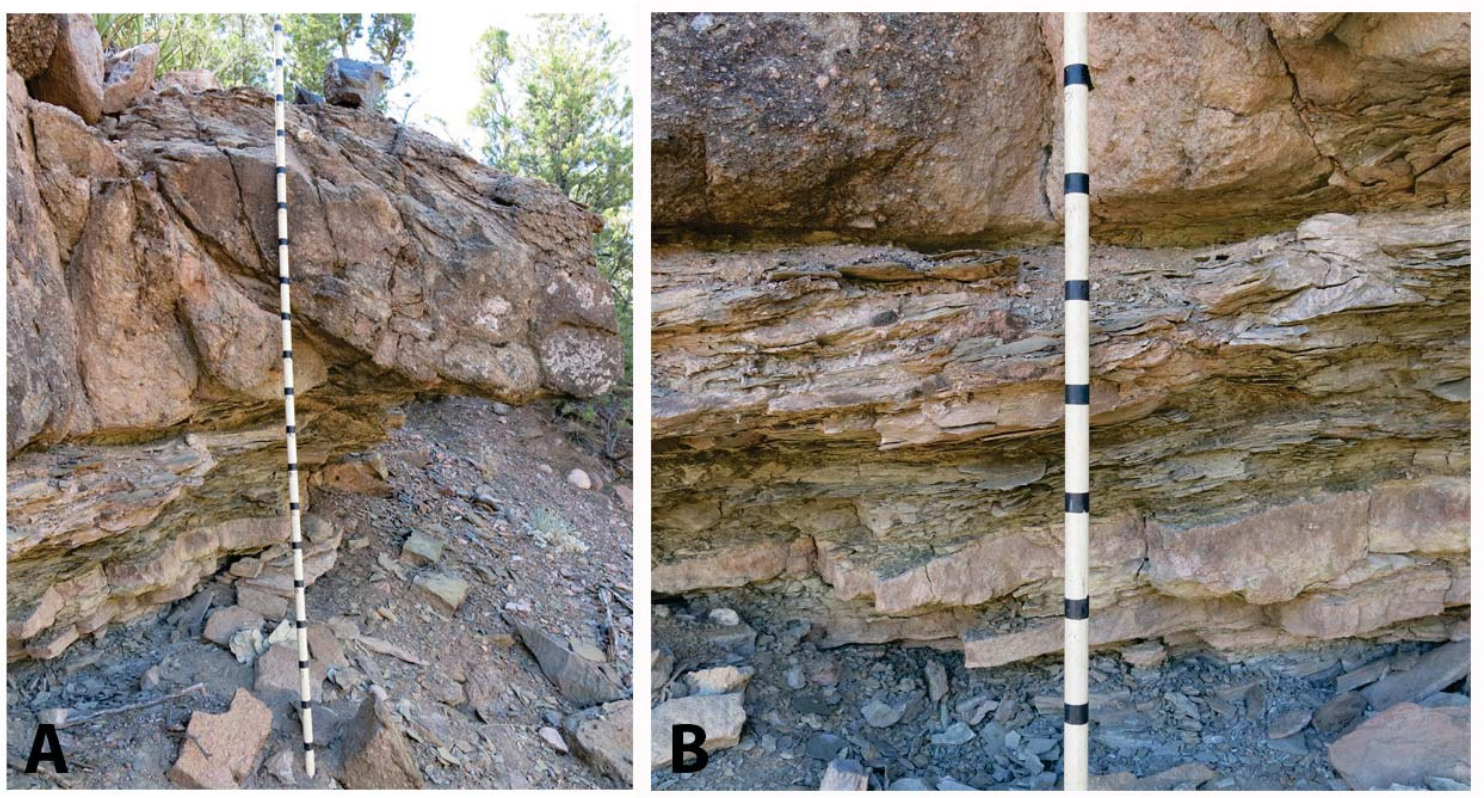

Figure 17. Field photographs of Site 2 (Jacob's staff marked in 10 centimeter increments). A. View of full outcrop. B. Middle fossil-bearing unit
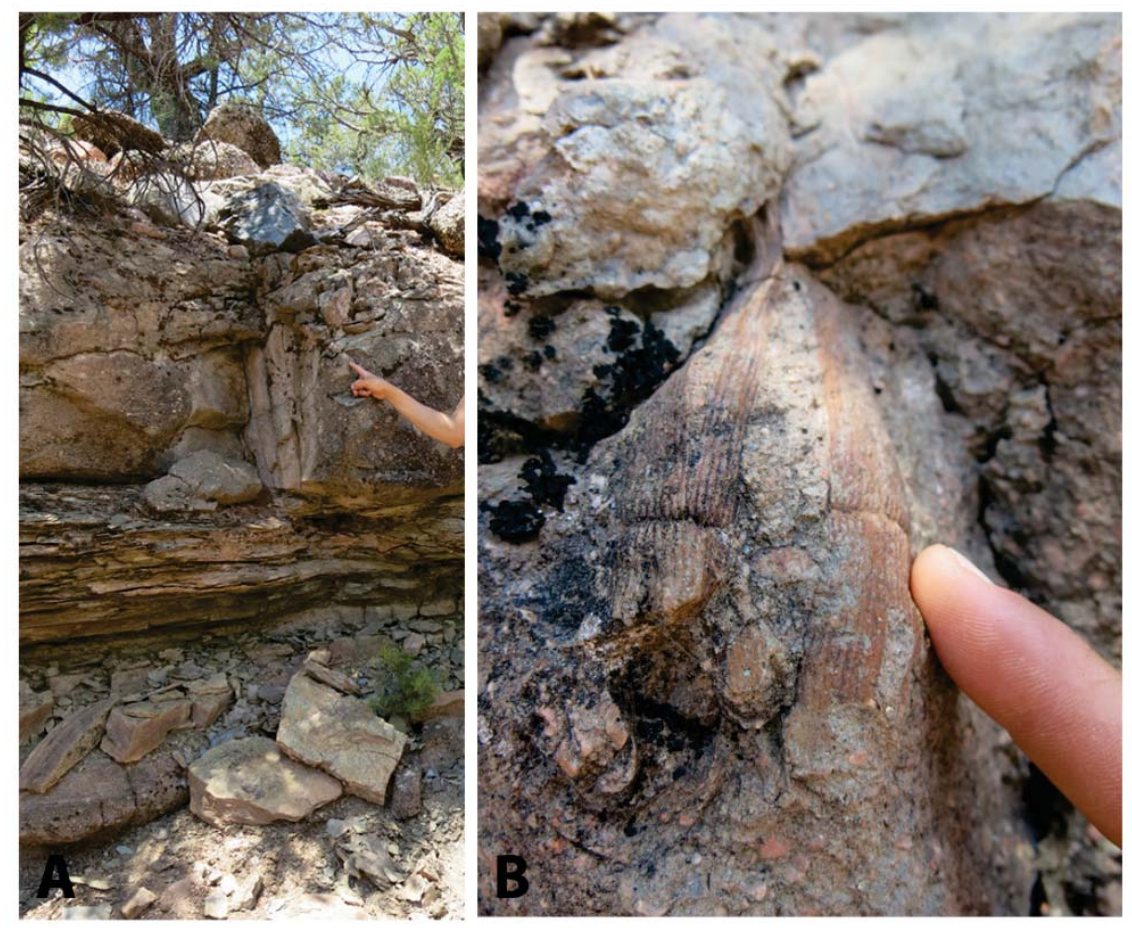

Figure 18.

Calamitean fragment in place near base of uppermost unit at Site 2. A. Outcropscale view. B. Close-up view of fragment. 


\section{Fossil Content}

Four identifiable plant fossils were collected from Site 2. One Pecopteris specimen (figure $19)$ is 3.5 centimeters in length and 4.5 centimeters at its widest point. A partial stem is visible with fragments of pinnae attached in a $\mathrm{V}$-shaped pattern. The pinnae are alternate and 2.2 to 3 centimeters long and 0.1 to 0.5 centimeters wide. Pinnae become thinner away from the site of attachment to the stem and come to a point at the distal tips. Similar to the Pecopteris specimen from Site 1, there are small pinnules with a broad basal attachment to the costa and slight confluence between adjacent pinnules (DiMichele and others, 2010). The specimen is olive gray within a dark greenish gray micaceous siltstone.

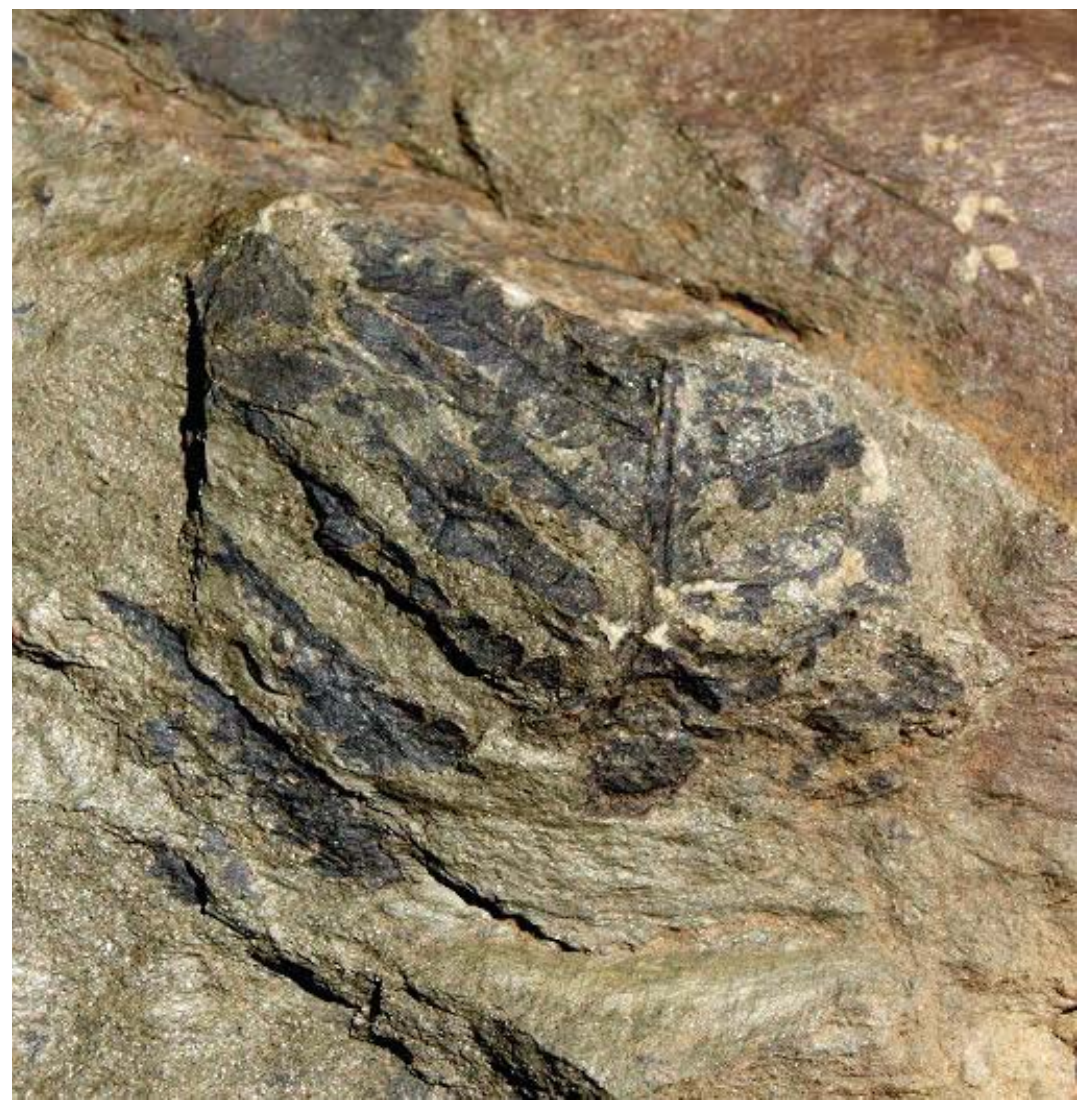

Figure 19. Pecopteris (specimen dimensions $=$ $3.5 \mathrm{~cm}$ x $4 \mathrm{~cm})$. USNM Specimen 611009. USNM Site 43856.

An additional Pecopteris specimen (figure 20) was collected from Site 2. The specimen is 3 centimeters long and 1 centimeter wide. The pinnules are 0.5 centimeters long, 0.4 centimeters wide, rounded, and adhered to the stem along the entire base. The pinnules are alternate, closely spaced and are generally attached nearly perpendicular to the mid-rib (Wittry, 2006). Sparse venation is present and appears to be widely forked and one-time divided, as is characteristic of pecopterids (DiMichele, personal communication, 2015). The fossil is grayish brown in a moderate yellowish brown siltstone. 


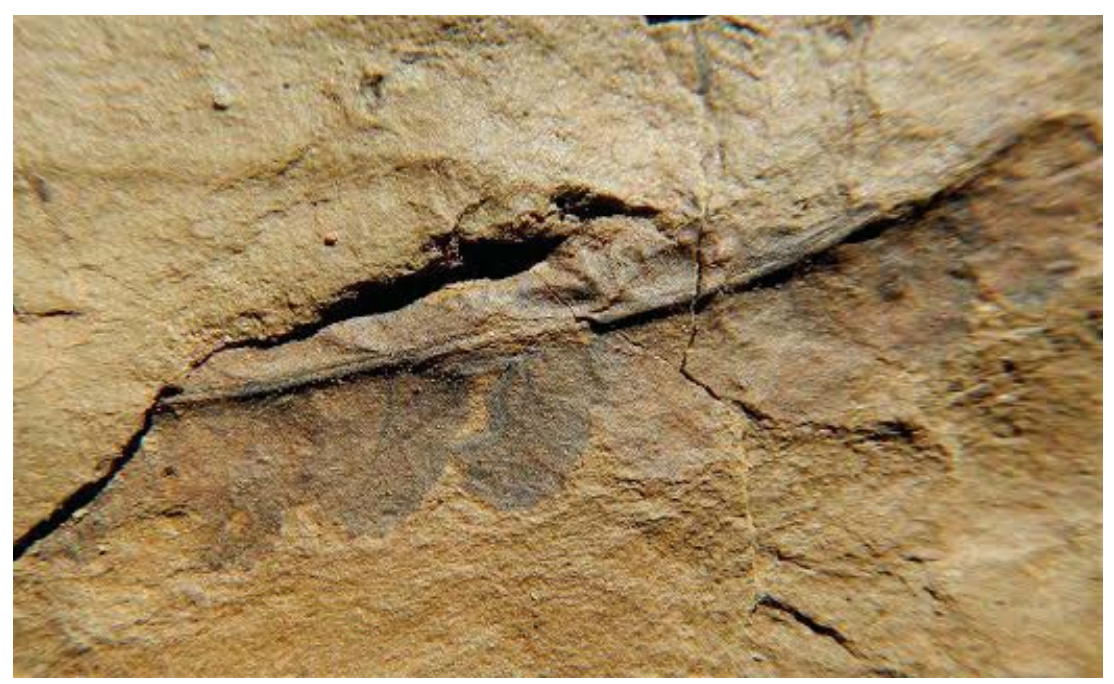

Figure 20. Pecopteris (specimen dimensions $=3 \mathrm{~cm} \times 1 \mathrm{~cm})$. USNM Specimen 611010. USNM Site 43856.

Additional Walchia specimens were collected at Site 2. The best preserved Walchia fossil (figure 21) from Site 2 is 2.8 centimeters long and 0.3 centimeters wide. The specimen is characterized by narrow branches with small, upright leaves that taper to a point (Arnold, 1941). The leaves are seed shaped and also come to a point where they are attached to the stem. Each leaf is 0.3 centimeters long and the average width is on the order of 0.1 centimeters. The fossil is brownish gray within a dark greenish gray micaceous siltstone.

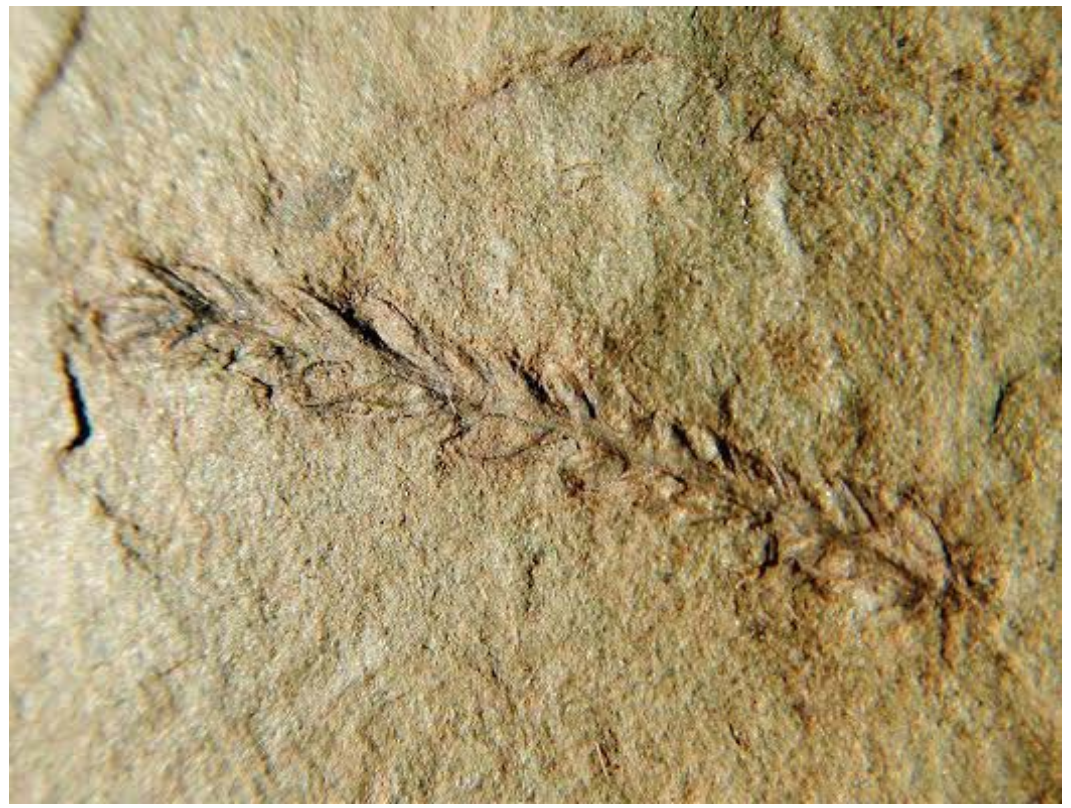

Figure 21. Walchia (specimen dimensions $=2.8 \mathrm{~cm} \times 0.3 \mathrm{~cm})$. USNM Specimen 611011. USNM Site 43856. 
A small fossil calamitean cone (figure 22), possibly from the genus Palaeostachya, is 1.8 centimeters long and 0.4 centimeters wide. The different kinds of calamitean cones cannot always be recognized without clear preservation of the spore-bearing organs (Arnold, 1958). The cone is incomplete because the base and stem are not visible. The central axis has regularly spaced discs with whorls of bracts extending from the sides (Arnold, 1958). The fossil is preserved as an olive gray impression in a dark greenish gray micaceous siltstone.

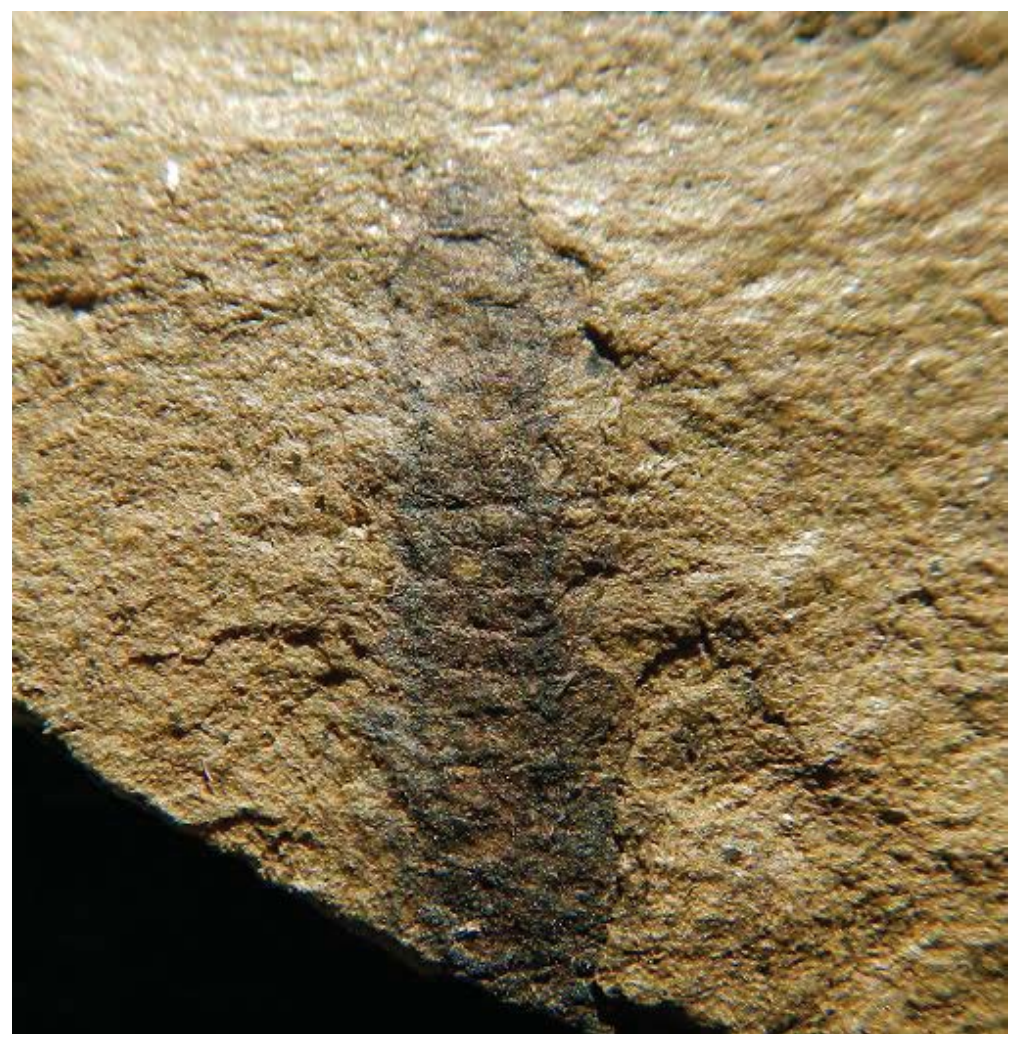

Figure 22. Fossil

calamitean cone (specimen dimensions $=1.8 \mathrm{~cm} \mathrm{x} 0.4$ $\mathrm{cm})$. USNM Specimen 611012. USNM Site 43856.

The sample collected at Site 2 and processed for organics contained a palynoflora that is similar to that of Site 1. Cellulosic tissue fragments were abundant, and Pennsylvanian spores were present but were extremely degraded. The common Pennsylvanian palynomorph, Thymospora pseudothiessenii, was identifiable in the sample from Site 2 (figure 23). Site 1 and Site 2 produced the most organic material, although pollen was sparse in samples from all three sites. It is not surprising that Sites 1 and 2 were the most productive, as these are the sites that also contained plant fossils. Sparse and degraded palynomorphs recovered from the Cutler Formation in this study are consistent with those reported in a previous study (Soreghan and others, 2007), as is the presence of modern contaminants and/or grains that have infiltrated from now eroded but previously overlying younger rocks. 


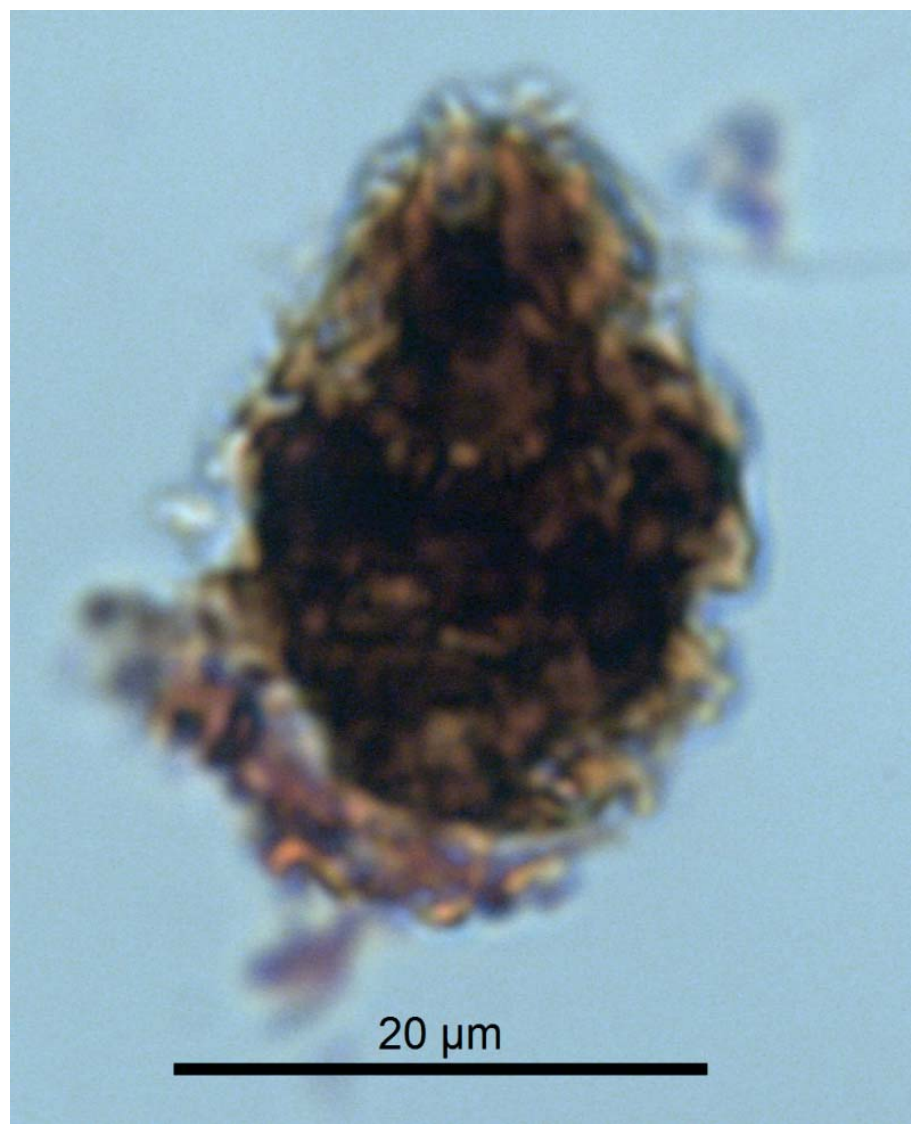

Figure 23. Degraded Thymospora pseudothiessenii (scale bar $=20$ $\mu \mathrm{m})$. USNM Site 43856.

Site Three

Site 3 (figure 24, USNM 43858) was sampled so that the material could be processed to determine whether or not it contained pollen, spores, or other organic material. Site 3 is a massive to cross stratified outcrop of lavender conglomerate that contains lenses of micaceous, platy siltstone. Lenses average 3 centimeters thick with the largest lenses reaching 5 centimeters in thickness. The sampled lens extended for several meters horizontally. The unit as a whole extended for several tens of meters along the west side of Bull Draw. The coarse-grained components of the unit contained angular clasts, averaging 1 centimeter in diameter, of feldspar and granite supported by matrix consisting of silt- to clay-sized particles. The fine-grained lenses are similar to the fossil-bearing layers present at Sites 1 and 2 in terms of grain size and platy texture, but the material at Site 3 is less micaceous than the fossil-bearing units at Sites 1 and 2. Site 3 did not contain any visible fossils. Organic material obtained from the sample collected at Site 3 contained late Paleozoic charcoal and palynomorphs that indicate contamination by modern pollen. 


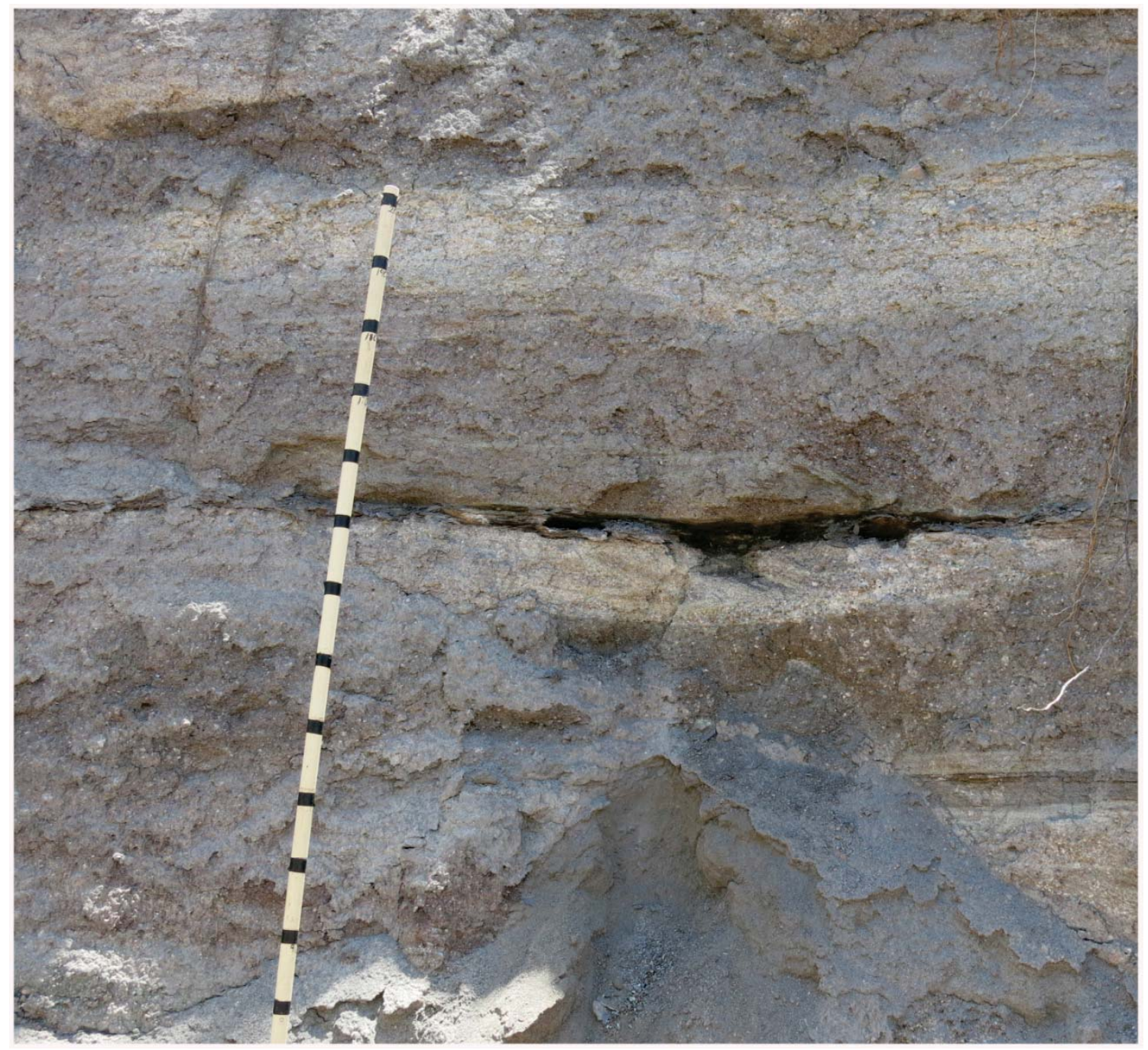

Figure 24. Field photograph of Site 3 (Jacob's staff marked in 10 centimeter increments). USNM Site 43858.

\section{DISCUSSION}

The flora found near Gateway is a mixture of species typical of seasonally dry environments as well as wetland settings. The characteristics of most of the plant fossils collected from the Cutler Formation indicate wet conditions at the time of growth (Tidwell, 1998). Preliminary analysis of the paleomagnetic signatures of the rocks in the collection area suggest a position near the equator, which would have produced warm temperatures (Mankowski, 2003). Warm, rainy, equatorial mires extended across parts of mid-continent North America during the Pennsylvanian (Scotese and McKerrow, 1990). Calamites has been found in both coal swamps and flood basins (Gastaldo, 1986; 1987), and proves to be 
tolerant of excessive flooding and sediment burial (Gastaldo and others, 1995: DiMichele and others, 2001). Pecopteris has been found in Carboniferous coal swamps as well as in relatively dry Permian environments (DiMichele and others, 2001).

Although most of the plants are interpreted to have lived in a wide variety of wetland settings, walchian conifers were stress-tolerant plants that lived in relatively dry habitats (Rothwell and others, 1997). Coniferous genera such as Walchia, have long been considered a common constituent of the Permian flora, but Walchia also occurs in association with typical Pennsylvanian genera (Arnold, 1941). The appearance of Walchia in the mid-continent region is thought to reflect increasing aridity (Arnold, 1941). The presence of Walchia in the Cutler Formation may be a good indication of the regional or background climate in the area at the time of deposition. Arid to semi-arid climate conditions in upland settings would have confined the wetland species described above to parts of the landscape with high water tables (DiMichele and others, 2014). The wettolerant plants may have grown in seasonally abandoned channels. Walchia would have grown all around these geographically limited wet areas. The wet areas were more favorable for fossil preservation, making the presence of wetland plants appear more abundant than they actual were at the time of growth (DiMichele and others, 2014).

The succession at Site 1 fines upward and reflects a decrease in depositional energy. The plant fossils occur at the top of the succession and were deposited under the lowest energies recorded by the rocks at the site. It is highly unlikely that the fragile plants would have survived transport under conditions like those that resulted in deposition of the first two layers (figure 7). It seems more probable that the plants were preserved close to or at the site in which they grew.

The stratigraphic succession at Site 2 contains information about the Cutler Formation and the preservation of its fossil content that supplements the data collected from Site 1. First, the plant fossils are present primarily in the finest layers. Substantial quantities of mica are also present in these layers. Given that shear stresses are required to move platy mica grains that are extremely small, these layers provide additional evidence of slack water conditions at the time of deposition. Second, the overall succession indicates variations in depositional energy at two scales. The most pronounced variation is found in the difference in lithology and grain size that is recorded by units 1 and 3 , as opposed to unit 2. Variations within unit 2 record changes in depositional energy at an even finer scale. Flow strength increased and decreased through time and plant fossils were preserved when slack water deposits were not eroded away during a subsequent high-energy flow event. The characteristics of units 1 and 3 suggest that these two units consist of material that weathered in place within the 
Uncompahgre Uplift and was flushed from the source area onto the Gateway Fan during a short-lived high discharge event.

Overall, the characteristics of the strata at Sites 1 and 2 (including debris-flow, fluvial, and slack-water deposits) support the hypothesis that the Cutler Formation near Gateway is the product of deposition in a proximal alluvial fan environment (Huntoon and others, 2014). It is likely that the area was at least seasonally and locally wet during deposition of the fossil-bearing strata. Semi-arid alluvial fans commonly are fed by localized water sources, such as springs (Hilgard, 1902). A spring may have provided water to support the growth of vegetation even if substantially drier conditions prevailed at the regional scale.

The plants must have grown in a protected setting, as they were preserved very close to the source area for sediment. The best possibility of a deposition site for the plant fossils is a low-lying area on the surface of the proximal alluvial fan (Huntoon and others, 2014). This area probably experienced slack water conditions at some times, as indicated by the presence of fine-grained material. The site must have also experienced rapid burial so that the plant material could be protected and preserved. Without rapid burial, the fragile plants and surrounding sediment would have been easily washed down fan and broken apart without a chance for fossil preservation.

It is likely the preservation site was an abandoned channel on the alluvial fan. Large floods in arid and semi-arid climates can cause avulsion of the main fan channel, shifting the locus of deposition to previously inactive parts of the fan (Chawner, 1935). Abandoned or blocked fluvial channels are generally recognized as good sites for the potential preservation of plant material in continental environments (Gastaldo and Demko, 2011).

Huntoon and others (2014) proposed a detailed model for the deposition of the proximal Cutler Formation. In their model, climate and sea-level change are the primary processes that control variability observed within the formation. During the late Paleozoic, sediment was eroded from the Uncompahgre Uplift and deposited in the adjacent Paradox Basin. During deposition, subsidence of the Paradox Basin foreland was an ongoing process resulting from faulting along the western margin of the Uncompahgre Uplift and compaction of previously deposited sediment (Huntoon and others, 2014). Deposition in a rapidly subsiding basin may have provided an environment that was conducive to fossil preservation even if arid or semi-arid and seasonal conditions were dominant in the region (Looy and others, 2014). Subsidence of the basin probably contributed to keeping the fossil-bearing strata at depths below the water table, as is required for the preservation of plant material (Gastaldo and Demko, 2011), even in proximal reaches of the alluvial fan. 
It is notable that both of the fossil-bearing sites were located directly to the west of the contact between the Cutler Formation and the Precambrian rocks of the Uncompahgre Uplift (figures 4 and 5). It is possible that proximity to the contact was important for the preservation of the plant material. Fluid movement within the contact zone may have been the source of springs that provided water for the plants while they were alive. Upon burial, proximity to the fault may have resulted in preferential cementation of the Cutler Formation adjacent to the contact. This study's lack of success in finding additional fossil locales does not rule out the possibility that additional plant fossil may eventually be obtained from the Cutler Formation in The Palisade WSA. It seems likely that future searches will be most successful if efforts are concentrated on finding well-cemented, fine-grained layers located near the contact (or other conduit for fluid flow, such as a fault). Excavations below the surface at some of the sites with poorly consolidated fine-grained materials exposed at the surface may also result in the discovery of additional plant fossils in the future as well.

It is significant to note that both Sites 1 and 2 contained organic remains that are common in Pennsylvanian rocks. The sample from Site 1 contained the Pennsylvanian fern spore, Lophotriletes microsaetosus, and the sample from Site 2 contained the Pennsylvanian palynomorph, Thymospora pseudothiessenii. The occurrence of these palynomorphs suggest that the age of the most proximal portions of the Cutler Formation in The Palisade WSA may be Pennsylvanian. The previous discovery of Archaeocalamites in the proximal Cutler Formation (Huntoon and others, 2014) would also suggest a Pennsylvanian age, as Archaeocalamites is more common during this age range and tends to be more rare in the Permian (DiMichele, personal communication, 2015; Mamay and Bateman, 1991).

This evidence is consistent with the late Pennsylvanian age determined by Mankowski (2003) based on analysis of the paleomagnetic signature of samples collected near the location of Sites 1 and 2. It is possible that the fossils are within layers that form the hanging wall of one of the intraformational faults (Mankowski, 2003) that cut the Cutler Formation in the Gateway area and place relatively older Cutler Formation above relatively younger Cutler Formation. Thus, even though these rocks are now exposed at the surface, they may be part of the older portion of the late Paleozoic Cutler Formation. Cutler Formation strata exposed along the margins of the Palisade are likely much younger and Permian in age, since they are clearly overlain by the Triassic Moenkopi Formation and therefore occupy the same stratigraphic position as Permian rocks that are present to the west in the central to western Paradox Bain (e.g., White Rim Sandstone, De Chelly Sandstone, Kaibab Limestone). Hence, The Palisade WSA contains rocks that reflect deposition throughout a significant portion of the late Paleozoic. 


\section{CONCLUSIONS}

The observations made of the Cutler Formation near Gateway indicate that the rocks were deposited in a proximal alluvial fan environment. The plant fossils collected suggest that warm and at least seasonally and locally wet conditions existed at some sites in the area at time of deposition of the Cutler Formation. Drier conditions prevailed across the majority of the landscape at that time. Traditionally, alluvial fans are sites of transport of large volumes of sediment and do not provide an ideal setting for fossil preservation. The plants must have grown in a protected setting, such as an abandoned channel in a low-lying area on the surface of the alluvial fan. The material was buried rapidly in a subsiding basin directly adjacent to the western margin of the Uncompahgre Uplift. The plant fossils and pollen evidence described in this paper support the interpretation that the climate in The Palisade WSA during the late Paleozoic was warm. There appears to have been abundant vegetation in and adjacent to low-lying wet areas at the time the Cutler Formation was deposited. 


\section{ACKNOWLEDGEMENTS}

We thank the Bureau of Land Management for its assistance with this project; it would not have been possible without the help and advice provided by Harley Armstrong, Madeline Grant-Hoffman, and David (Scott) Gerwe. The work was conducted under United States Department of the Interior Bureau of Land Management Colorado State Office Paleontological Resources Use Permits COC76491 and COC76492. We thank Bill DiMichele for his assistance and patience in helping us to identify and interpret plant material collected for this and other studies of the Cutler Formation. We also thank Dr. DiMichele for agreeing to allow us to use the National Museum of Natural History as the repository for our samples. We thank Dan Chaney for his guidance in preparing the samples for shipment to the Smithsonian. We thank Jack Stanesco for his assistance in the field. Finally, we thank the Michigan Space Grant Consortium for its financial support, which made it possible for the first author to first visit the study area during a field-based course for pre-college teachers that was taught by the second author and offered as a graduate course by Michigan Technological University. 


\section{REFERENCES}

Arnold, C.A., 1941, Some Paleozoic plants from central Colorado and their stratigraphic significance: Contributions from the Museum of Paleontology, University of Michigan, v. 6, no. 4, p. 59-70.

Arnold, C.A., 1958, Petrified cones of the genus Calamostachys from the Carboniferous of Illinois: Contributions from the Museum of Paleontology, University of Michigan, v. 14, no. 10, p. 149-165.

Campbell, J.A., 1979, Lower Permian depositional system, northern Uncompahgre Basin, in Baars, D.L., editor, Permianland field symposium: Four Corners Geological Society, Guidebook 9, p. 13-21.

Campbell, T.L., 2003, Paleoclimatic implications of the Cutler Formation, undivided (Pennsylvanian-Permian), near Gateway, Colorado: Houghton, Michigan Technological University, M.S. thesis, 95 p.

Cater, F.W., Jr., 1955, Geology of the Gateway quadrangle, Colorado: U.S. Geological Survey Quadrangle Map GQ-55, 1 sheet, scale 1:24,000.

Chawner, W.D., 1935, Alluvial fan flooding, the Montrose, California flood of 1934: Geographical Review, v. 25, p. 255-263.

Condon, S.M., 1997, Geology of the Pennsylvanian and Permian Cutler Group and Permian Kaibab Limestone in the Paradox Basin, southeastern Utah and southwestern Colorado: U.S. Geological Survey Bulletin 2000-P, 46 p.

DiMichele, W.A., Cecil, C.B., Chaney, D.S., Elrick, S.D., and Nelson, W.J., 2014, Fossil Floras from the Pennsylvanian-Permian Cutler Group of southeastern Utah, in MacLean, J.S., Biek, R.F., and Huntoon, J.E., editors, Geology of Utah's Far South: Utah Geological Association Publication 43, p. 491-504.

DiMichele, W.A., Chaney, D.S., Kerp, H., and Lucas, S.G., 2010, Late Pennsylvanian floras in western equatorial Pangea, Cañon del Cobre, New Mexico: New Mexico Museum of Natural History and Science Bulletin, v. 49, p. 75-113. 
DiMichele, W.A., and Falcon-Lang, H.J., 2012, Calamitalean "pith casts" reconsidered: Review of Palaeobotany and Palynology, v. 173, p. 1-14.

DiMichele, W.A., Pfefferkorn, H.W., and Gastaldo, R.A., 2001, Response of Late Carboniferous and Early Permian plant communities to climate change: Annual Reviews of Earth and Planetary Sciences, v. 29, p. 461-487.

Gastaldo, R.A., 1986, Implications on the paleoecology of autochthonous lycopods in clastic sedimentary environments of the Early Pennsylvanian of Alabama: Palaeogeography, Paleoclimatology, Palaeoecology, v. 53, no. 2-4, p. 191-212.

Gastaldo, R.A., 1987, Confirmation of Carboniferous clastic swamp communities: Nature, v. 326, p. 869-871.

Gastaldo, R.A., and Demko, T.M., 2011, The relationship between continental landscape evolution and the plant-fossil record - long term hydrological controls on preservation, in Allison, P.A., and Bottjer, D.J., editors, Taphonomy - process and bias through time: Topics in Geobiology 32, p. 249-285.

Gastaldo, R.A., Pfefferkorn, H.W., and DiMichele, W.A., 1995, Taphonomic and sedimentologic characterization of roof-shale floras, in Darrah, W.C., and Lyons, P.C., editors, Historical perspective of early twentieth century Carboniferous paleobotany: Geological Society of America Memoir 185, p. 341-352.

Hilgard, E.W., 1902, The debris fans of the arid region in their relation to the water supply, $3^{\text {rd }}$ annual meeting of the Cordilleran Section of the Geological Society of America: Science, v. 15 , no. 376 , pg. 414.

Hite, R.J., and Buckner, D.H., 1981, Stratigraphic correlations, facies concepts, and cyclicity in Pennsylvanian rocks of the Paradox Basin, in Weigand, D.L., editor, Geology of the Paradox Basin: Rocky Mountain Association of Geologists, p. 147159.

Huntoon, J.E., Boks, K., Mankowski, L., Campbell Wyrembelski, T.L., Dubiel, R.F., and Stanesco, J.D., 2014, Fossil plants from a proximal alluvial-fan complex: implications for late Paleozoic sedimentary processes in western tropical Pangea, in MacLean, J.S., Biek, R.F., and Huntoon, J.E., editors, Geology of Utah's Far South: Utah Geological Association Publication 43, p. 473-490. 
Looy, C.V., Kerp, H., Duijnstee, I.A.P., and DiMichele, W.A., 2014, The late Paleozoic ecological-evolutionary laboratory, a land-plant fossil record perspective: The Sedimentary Record, v. 12, no.4, p. 4-10.

Mack, G.H., and Rasmussen, K.A., 1984, Alluvial-fan sedimentation of the Cutler Formation (Permo-Pennsylvanian) near Gateway, Colorado: Geological Society of America Bulletin, v. 95, p. 109-116.

Mamay, S.H., and Bateman, R.M., 1991, Archaeocalamites lazarii, sp. nov.-the range of Archaeocalamitaceae extended from the lowermost Pennsylvanian to the midLower Permian: American Journal of Botany, v. 78, no. 4, p. 489-496.

Mankowski, L.C., 2003, Structural mapping of the Uncompahgre front near Gateway, Colorado-field evidence of an ancestral Rocky Mountain decollement: Houghton, Michigan Technological University, M.S. thesis, 88 p.

Nuccio, V.F., and Condon, S.M., 1996, Burial and thermal history of the Paradox Basin, Utah and Colorado, and petroleum potential of the Middle Pennsylvanian Paradox Formation: Utah Geological Association Guidebook, Geology and Resources of the Paradox Basin.

O'Keefe, J.M.K., Hower, J.C., Hatch, R., and Bartley, S., 2011. Fungal forms in Miocene Eel River coals: extraction across a rank suite, in $44^{\text {th }}$ Annual Meeting of AASP The Palynological Society, Southampton, United Kingdom, program with abstracts.

O'Keefe, J.M.K., and Eble, C.F., 2012, A comparison of HF-based and non HF-based palynology processing techniques in clay-rich lignites from the Claiborne Group, upper Mississippi Embayment, United States, Palynology 36, p. 116-130.

Rankey, E.C., 1997, Relations between relative changes in sea level and climate shiftsPennsylvanian-Permian mixed carbonate-siliciclastic strata western United States: Geological Society of America Bulletin: v. 109, no. 9, p. 1089-1100.

Rothwell, G.W., Maples, G., and Mapes, R.H., 1997, Late Paleozoic conifers of North America: structure, diversity and occurrences: Review of Palaeobotany and Palynology, v. 95, no.1, p. 95-113. 
Scotese, C.R., and McKerrow, W.S., 1990, Revised world maps and introduction: Geological Society, London, Memoirs, v. 12, no. 1, p. 1-21.

Soreghan, G.S., Sweet, D.E., Marra, K.R., Eble, C.F., Soreghan, M.J., Elmore, R.D., Kaplan, S.A., and Blum, M.D., 2007, An exhumed late Paleozoic landscape in the Rocky Mountains: Journal of Geology, v. 115, p. 473-481.

Soreghan, G.S., Soreghan, M.J., Sweet, D.E., and Moore, K.D., 2009, Hot fan or cold outwash? Hypothesized proglacial deposition in the upper Paleozoic Cutler Formation, western tropical Pangea: Journal of Sedimentary Research, v. 79, p. 495-522.

Tidwell, W.D., 1998, Common fossil plants of western North America, $2^{\text {nd }}$ edition: Washington, Smithsonian Institution Press, pp. 38-39, 70-71, 87-88, 90.

Walker, T.R., 1967, Formation of redbeds in modern and ancient deserts: Geological Society of America Bulletin, v. 78, p. 353-368.

Werner, W.G., 1974, Petrology of the Cutler Formation (Pennsylvanian-Permian) near Gateway, Colorado, and Fisher Towers, Utah: Journal of Sedimentary Petrology, v. 44 , p. 292-298.

Wittry, J., 2006, The Mazon Creek fossil flora: Downers Grove, Esconi Associates, 154 p.

Ye, H., Royden, L., Burchfiel, C., and Schuepbach, M., 1996, Late Paleozoic deformation of interior North America: the greater Ancestral Rocky Mountains, American Association of Petroleum Geologists Bulletin, v. 80, no. 9, p. 1397-1432. 